\title{
諸種利尿劑，特に脂肪酸墖類，尿素及びプリン 誘導體の經口的適用によろ作用比較
}

\author{
君塚 通 雄
}

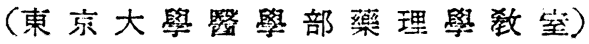

(昭和二十五年十二月十七日受附)

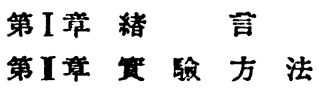

第 1 管 验勤物

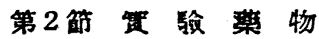

第3 管 探 尿方法

第 4 節 推計學に基いた然駼計㯰法

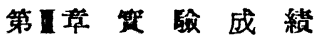

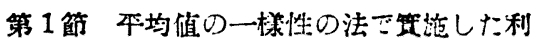
家虹授

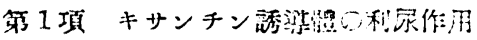

第 2 项 尿集, 鼠化打里门和尿作成
次

第 3 項 有機脂肋酸監類の利尿作用

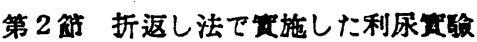

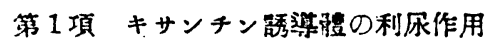

第 2 項 有機脂肘酸監類の利尿作用

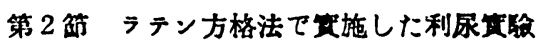

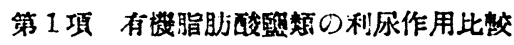

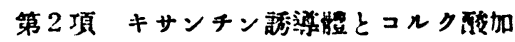
里の利疗作用比较

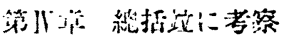

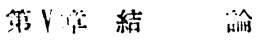

\section{第I章 緒言}

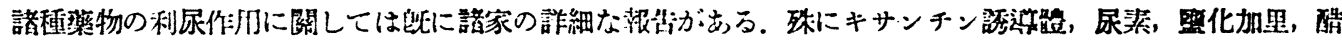

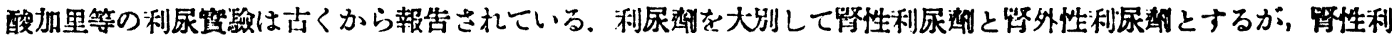

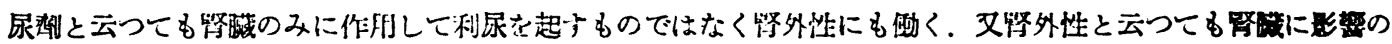

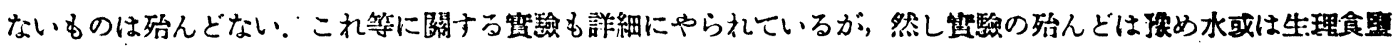

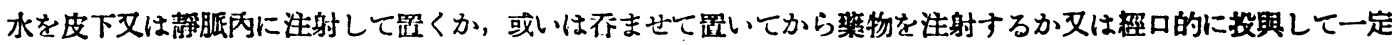

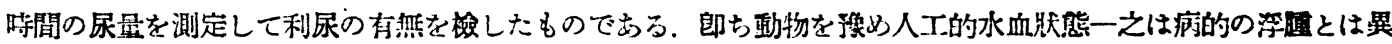

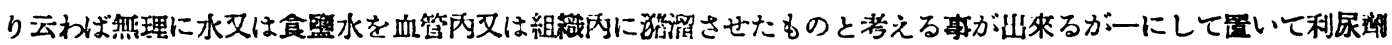

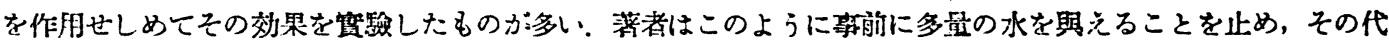

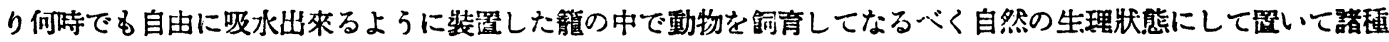

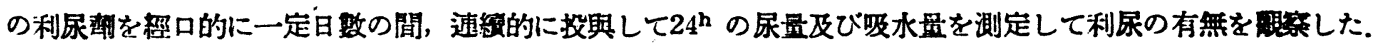

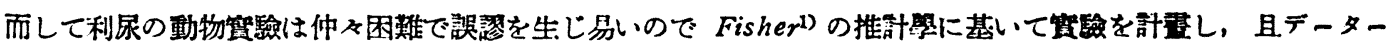
は推計掔的检定を行つて正確を期した，その結果以下の如き成綪を得たので获に報告する:

\section{第片草宾睛方法

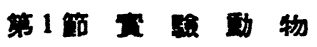

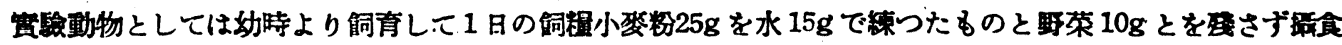

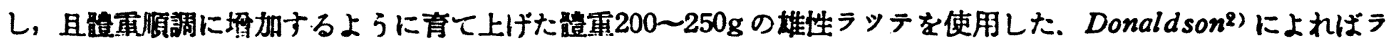

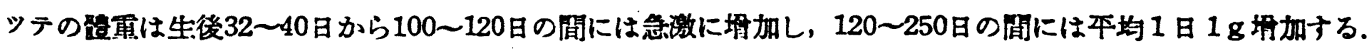

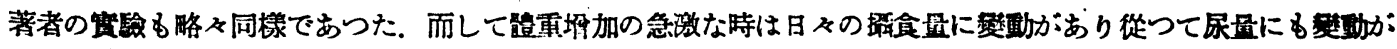

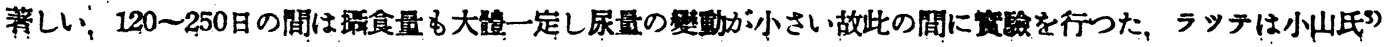




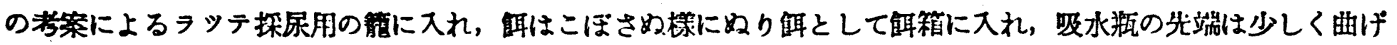

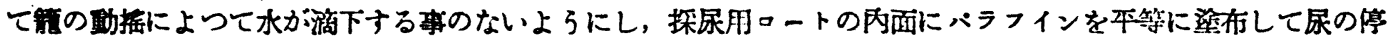

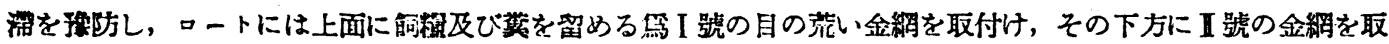

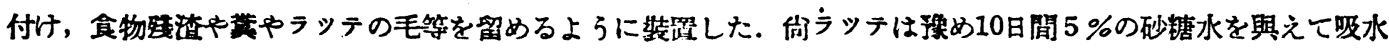

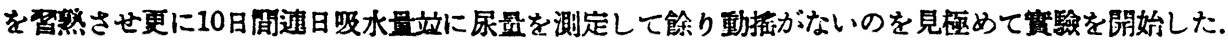

第 2 節 跧 藥 物

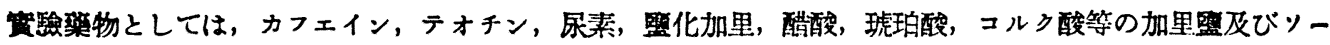
タ蛪を使用した。

第3䈏探 尿方 法

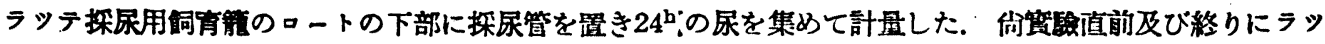
テの腹部を厴して排尿せしめ尿の然溜による誤差を少くする栐に娢めた。

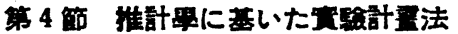

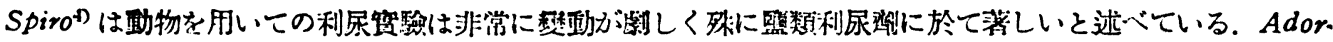
$p h^{5)}$ ，Thompson

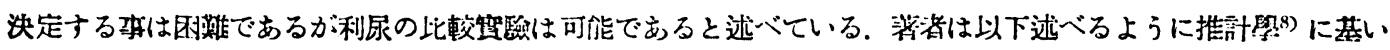

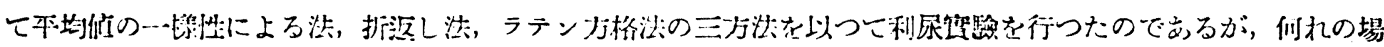

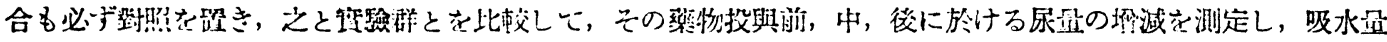

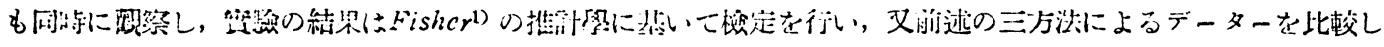
てその價傎を喻討した。

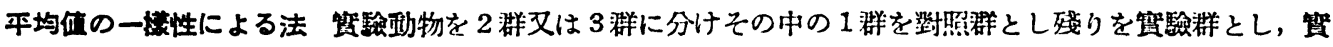

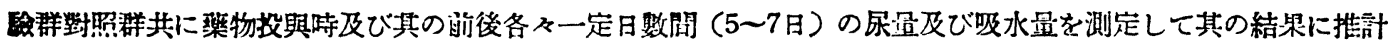
學的检討を加えて價値制定を行つた。

折返し法 寞蕗動物を 2 群に分け第 1 群は最初の 5 日間所要の藥物を投與し，次の 5 日問は投與を中止し， 最後の 5 日問再び同量の集物を投與した．第 2 群は中の 5 日閒の々菜物を投與しその前後の 5 日間は樂物を與え ずに尿贯及び吸水贯を測定した。

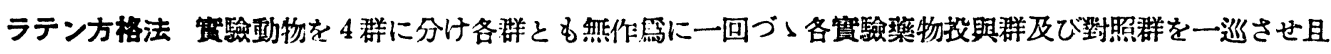

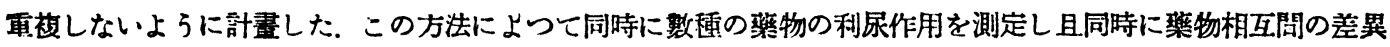
を比較检定した。

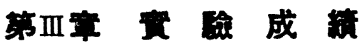

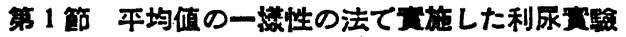

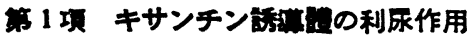

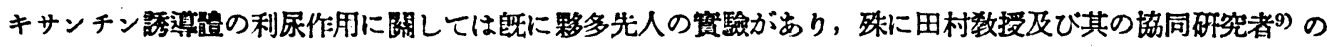

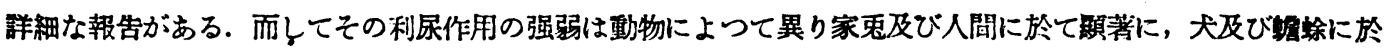

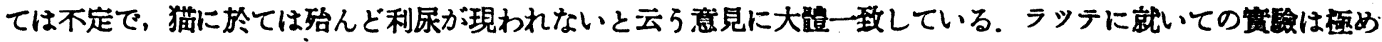
て少く信赖すべきすのを見ない，元來キサンチン誘導體の利尿作用は全身浮腫又は水血狀態がある時强い利尿作

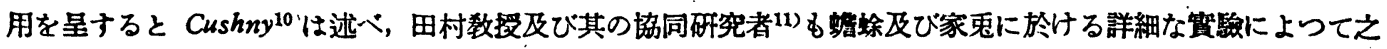

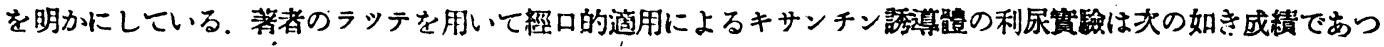
た（第1～表照). 


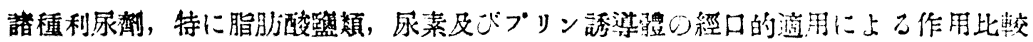

第 1 表. 平均值の一樣性の法によるカフェイン $10 \mathrm{mg}$ 及び $30 \mathrm{mg} / \mathrm{kg}$ 經口设與による利尿及び吸水椠驗。

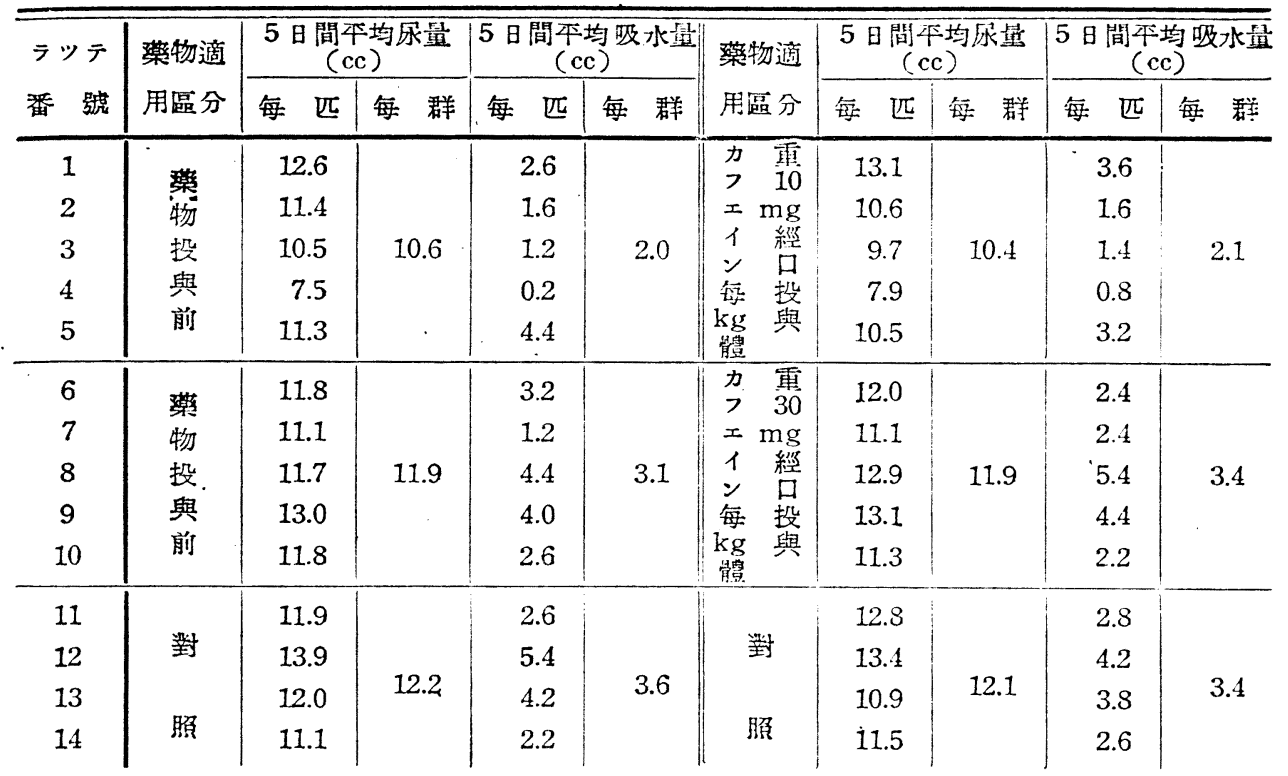

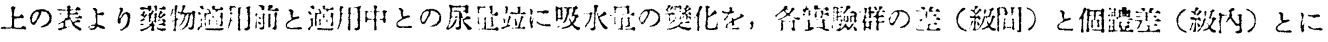

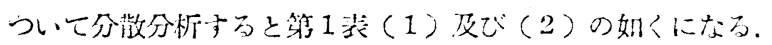

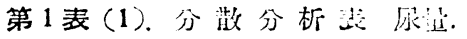

\begin{tabular}{|c|c|c|c|c|c|}
\hline 要因 & 紮動 & 自由度 & 不偏分散 & $F_{0}$ & $\mathrm{~F}$ \\
\hline 級間 & 0.627 & 2 & 0.3134 & 0.59 & $0.05)=3.98$ \\
\hline 級內 & $5.82 €$ & 11 & 0.5299 & & \\
\hline
\end{tabular}

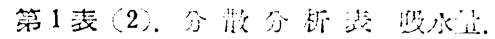

\begin{tabular}{|c|c|c|c|c|c|}
\hline 荌因 & 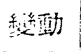 & 白由度 & 不僻分散 & $F_{0}$ & $\mathrm{~F}$ \\
\hline 級間 & 0.571 & 2 & 0.285 & 0.4 & $.05)=3.98$ \\
\hline 級內 & 7.326 & 11 & 0.666 & & \\
\hline
\end{tabular}

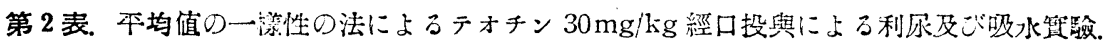

\begin{tabular}{|c|c|c|c|c|c|c|c|c|c|c|c|c|c|c|c|}
\hline \multirow{2}{*}{$\begin{array}{l}\text { ラッテ } \\
\text { 番號 }\end{array}$} & \multirow{2}{*}{ 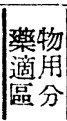 } & \multicolumn{2}{|c|}{$\begin{array}{l}5 \text { 日間本均 } \\
\text { 尿量 (cc) }\end{array}$} & \multicolumn{2}{|c|}{$\begin{array}{l}5 \text { 日間本均 } \\
\text { 吸水量(cc) }\end{array}$} & \multirow{2}{*}{ 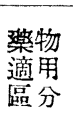 } & \multicolumn{2}{|c|}{$\begin{array}{l}5 \text { 日間本均 } \\
\text { 疗量 (cc) }\end{array}$} & \multicolumn{2}{|c|}{$\begin{array}{l}5 \text { 日間本均 } \\
\text { 吸水量(cc) }\end{array}$} & \multirow{2}{*}{$\begin{array}{l}\text { 省物 } \\
\text { 燠角 } \\
\text { 區分 }\end{array}$} & \multicolumn{2}{|c|}{$\begin{array}{l}5 \text { 日間平均 } \\
\text { 㽷量 (cc) }\end{array}$} & \multicolumn{2}{|c|}{$\begin{array}{l}5 \text { 日間平均 } \\
\text { 吸水量 }(\mathrm{cc})\end{array}$} \\
\hline & & 每匹 & 每群 & 每區 & 每群 & & 每匹 & 每群 & 每匹 & 每群 & & 短匹 & 每群 & 每匹 & 每群 \\
\hline 1 & & 9.0 & & 0.7 & & テ經 & 10.3 & & 0.8 & & & 8.7 & & 1.3 & \\
\hline 2 & 蔡 & 13.2 & & 3.7 & & $\begin{array}{l}\text { オ口 } \\
\text { 千投 }\end{array}$ & 13.2 & & 38 & & 藥 & 12.9 & & 3.3 & \\
\hline 3 & 物 & 13.1 & & 4.1 & & 之與 & 11.8 & & 4.6 & & & 13.1 & & 4.8 & \\
\hline 4 & 投 & 10.5 & 11.2 & 1.9 & 2.4 & $\begin{array}{l}\text { 每 } \\
\text { kg }\end{array}$ & 10.7 & 11.2 & 1.9 & 2.4 & 投 & 10.2 & 11.0 & 1.3 & 2.4 \\
\hline 5 & 與 & 10.8 & & 2.1 & & 體 & 10.0 & & 1.8 & & 與 & 9.9 & & 1.6 & \\
\hline 6 & 前 & 10.9 & & 2.1 & & 草 & 11.5 & & 2.0 & & 中 & 10.7 & & 1.8 & \\
\hline 7 & & 10.9 & & 2.4 & & $\mathrm{mg}$ & 11.0 & & 2.3 & & 止 & 11.3 & & 2.9 & \\
\hline 8 & & 11.8 & & 1.8 & & & 10.0 & & 1.4 & & & 10.2 & & 1.4 & \\
\hline 9 & 数 & 14.5 & & 5.1 & & 對 & 13.0 & & 4.0 & & 数 & 13.7 & & 4.3 & \\
\hline 10 & & 8.8 & & 1.5 & & & 10.2 & & 1.9 & & & 9.5 & & 2.2 & \\
\hline 11 & & 11.6 & 11.5 & 2.5 & 2.9 & & 11.4 & 11.0 & 2.5 & 2.6 & & 11.3 & 11.1 & 2.2 & 2.6 \\
\hline 12 & - & 14.6 & & 5.9 & & & 13.8 & & 5.4 & & & 14.0 & & 4.8 & \\
\hline 13 & 膗 & 13.0 & & 3.2 & & 照 & 11.2 & & 2.1 & & 照 & 11.8 & & 2.5 & \\
\hline 14 & & 6.6 & & 0.5 & & & 7.7 & & 1.0 & & & 7.2 & & 0.7 & \\
\hline
\end{tabular}




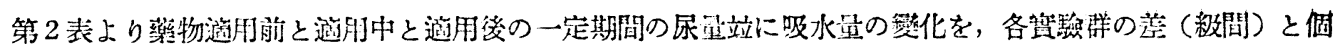

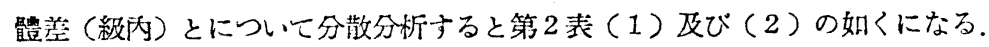

第 2 表 (1). 分散分析表 尿显.

\begin{tabular}{|c|c|c|c|c|}
\hline 要因 & 禁動 & 自由度 & 不偏分政 & $\mathrm{F}_{0}$ \\
\hline 級闒 & 4.512 & 1 & 4.512 & $1.8<\mathrm{F}_{1} \ddot{1}(0.05)=4.75$ \\
\hline 級肉 & 3.905 & 12 & 2.472 & \\
\hline
\end{tabular}

第 2 表 (2). 分散 分析洼 吸水望.

\begin{tabular}{|c|c|c|c|c|c|}
\hline 要因 & 綮酰 & 自由度 & 不偏分散 & $F_{0}$ & $F$ \\
\hline 級間 & 0.411 & 1 & 4.11 & 0.8 & $.05)=4.75$ \\
\hline 級內 & 6.006 & 12 & 0.5005 & & \\
\hline
\end{tabular}

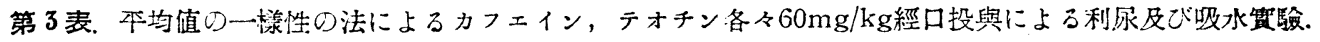

\begin{tabular}{|c|c|c|c|c|c|c|c|c|c|c|c|c|c|c|c|}
\hline \multirow{2}{*}{$\begin{array}{l}\text { ラッテ } \\
\text { 番號 }\end{array}$} & \multirow{2}{*}{ 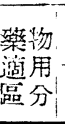 } & \multicolumn{2}{|c|}{$\begin{array}{l}7 \text { 日閴平均 } \\
\text { 辰致 (cc) }\end{array}$} & \multicolumn{2}{|c|}{$\begin{array}{r}7 \text { 日間平均 } \\
\text { 吸水量 (cc) }\end{array}$} & \multirow{2}{*}{ 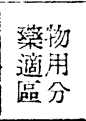 } & \multicolumn{2}{|c|}{ 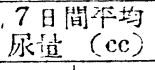 } & \multicolumn{2}{|c|}{$\begin{array}{c}7 \text { 日间阼均 } \\
\text { 吸水型 }\end{array}$} & \multirow{2}{*}{ 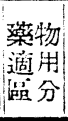 } & \multicolumn{2}{|c|}{ 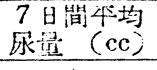 } & \multicolumn{2}{|c|}{$\begin{array}{r}7 \text { 日間 } \\
\text { 吸均盐( }(\mathrm{cc})\end{array}$} \\
\hline & & 每匹 & 每群 & 每匹 & 每祥 & & 每匹 & 每群 & 每匹 & 每群 & & 每匹 & 每群 & 敏匹 & 每群 \\
\hline 1 & 薄 & 6.0 & & 0.6 & & 力 $k g$ & 5.5 & & 08 & & 萦 & 6.6 & & 0.5 & \\
\hline 2 & 物 & 5.7 & & 1.1 & & & 5.8 & & 0.3 & & & 7.3 & & 1.5 & \\
\hline 3 & 起。 & 5.4 & 5.5 & 0.9 & 0.8 & 160 與 & 5.2 & 5.4 & 0.7 & 0.3 & 與 & 4.8 & 5.8 & 0.5 & 0.8 \\
\hline 4 & 㬏 & 4.8 & & 0.6 & & $\mid$ & 5.0 & & 0.7 & & 歨 & 4.5 & & 0.8 & \\
\hline 5 & 荣 & 3.9 & & 0.3 & & テ跤口 & 5.2 & & 0.7 & & 荣荌 & 4.0 & & 0.5 & \\
\hline 6 & 物 & 6.1 & & 1.9 & & 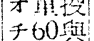 & 5.8 & & 1.7 & & & 4.8 & & 1.2 & \\
\hline 7 & 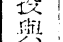 & 6.9 & 5.1 & 2.5 & 1.6 & $\because \mathrm{ms}$ & 6.0 & 0.7 & 1.8 & 1.4 & 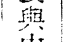 & 6.9 & 5.4 & 2.9 & 1.4 \\
\hline 8 & iifi & 6.0 & & 1.6 & & $\begin{array}{l}\text { l]. } \\
\mathrm{kg}\end{array}$ & 5.3 & & $1 . \overline{3}$ & & & 5.8 & & 0.8 & \\
\hline 9 & & 5.4 & & 0.8 & & & 5.9 & & 0.9 & & & 5.0 & & 0.7 & \\
\hline 10 & $\pm=1$ & ' 5.4 & & 0.9 & & 活于 & 4.6 & & 0.7 & & to & 4.9 & & 0.2 & \\
\hline 11 & & 4.6 & 5.4 & 0.5 & 0.9 & & 4.7 & 5.4 & 0.6 & 0.9 & & 5.1 & 5.3 & 0.8 & 0.8 \\
\hline 12 & 殒 & 6.1 & & 1.2 & & 朌 & 6.5 & & 1.5 & & 影 & 6.2 & & 1.6 & \\
\hline
\end{tabular}

第 3 表老第 2 垶と同㨾分散分析する。

第3表 (1). 分散分析表疗留.

\begin{tabular}{|c|c|c|c|c|c|}
\hline 要因 & 綮動 & 自由度 & 不偏分散 & $F_{0}$ & $\mathrm{~F}$ \\
\hline 級間 & I.582 & 2 & 0.792 & 0.41 & $.05)=4.26$ \\
\hline 級內 & 17.234 & 9 & 1.915 & & \\
\hline
\end{tabular}

第3表(2). 分散分析视 吸水堽.

\begin{tabular}{|c|c|c|c|c|}
\hline 要因 & 變動 & 白由度 & 不偏分散 & $F_{0}$ \\
\hline 級間 & 0.326 & 2 & 0.163 & $0.30<\mathrm{F}_{9}^{2}(0.05)=4.26$ \\
\hline 級內 & 4.823 & 9 & 0.536 & \\
\hline
\end{tabular}

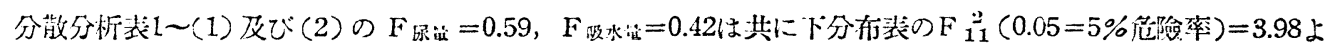

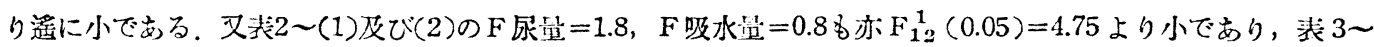

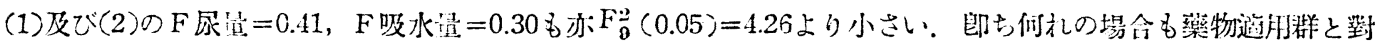

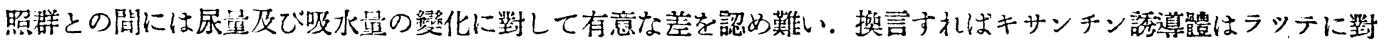
して經口的通用によつては，動物體が生理的狀態にある時は㱠儿ど利尿作用を現わさない，例命利尿があつても

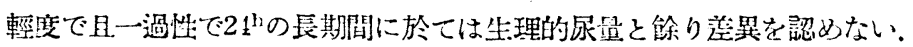

\section{第 2 項 尿素, 颠化加里の利尿作用}

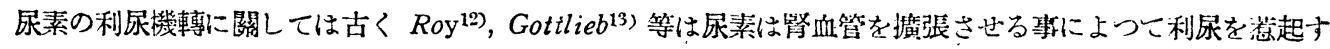

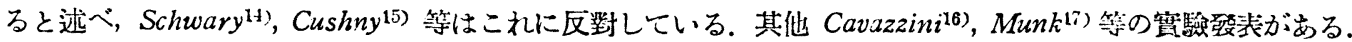

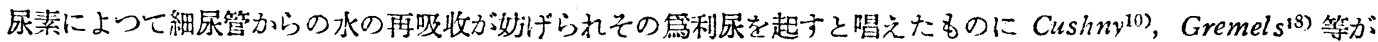

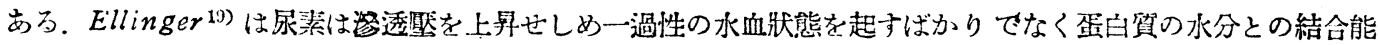

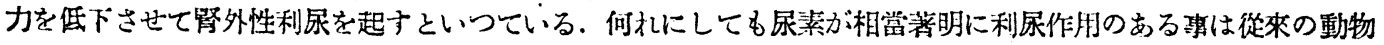




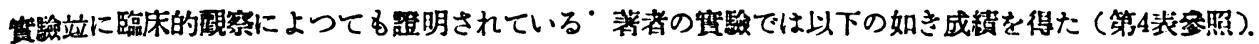

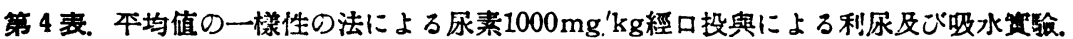

\begin{tabular}{|c|c|c|c|c|c|c|c|c|c|c|c|c|c|c|c|}
\hline \multirow{2}{*}{$\begin{array}{l}\text { テッテ } \\
\text { 番號 }\end{array}$} & \multirow{2}{*}{ 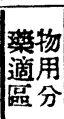 } & \multicolumn{2}{|c|}{$\begin{array}{l}6 \text { 旺間平均 } \\
\text { 尿量 }\end{array}$} & \multicolumn{2}{|c|}{ 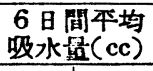 } & \multirow{2}{*}{$\begin{array}{l}\text { 䕁物 } \\
\text { 適分 }\end{array}$} & \multicolumn{2}{|c|}{$\begin{array}{l}\text { 6日間平均 } \\
\text { 水量 }(\mathrm{cc})\end{array}$} & \multicolumn{2}{|c|}{ 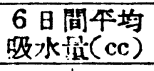 } & \multirow{2}{*}{ 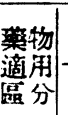 } & \multicolumn{2}{|c|}{ 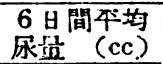 } & \multicolumn{2}{|c|}{ 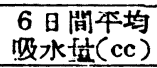 } \\
\hline & & 每匹 & 每群 & 每匹 & 每群 & & $0:$ 每 & 每群 & 每匹 & 每咩 & & 每匹 & 每群 & 每匹 & 每群 \\
\hline 1 & & 8.8 & & 0 & & & 7.8 & & 0 & & & 8.2 & & 0 & \\
\hline 2 & 對 & 14.1 & & 7.5 & & 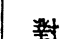 & 14.3 & & 11.8 & & 對 & 14.7 & & 8.2 & \\
\hline 3 & & 11.5 & & 7.3 & & & 11.5 & & 6.7 & & & 11.3 & & 7.2 & \\
\hline 4 & & 7.8 & 10.0 & 2.2 & 3.3 & & 9.0 & 10.0 & 2.0 & 3.7 & & 9.2 & 10.0 & 1.7 & 3.7 \\
\hline 5 & & 8.3 & & 3.0 & & & 8.4 & & 2.8 & & & 8.8 & & 3.2 & \\
\hline 6 & 䁖 & 11.7 & & 2.5 & & 照 & 11.3 & & 2.0 & & 照 & 10.0 & & 2.0 & \\
\hline 7 & & 7.6 & & 0.3 & & & 7.7 & & 0.8 & & & 7.9 & & 3.3 & \\
\hline 8 & 新 & 12.3 & & 6.5 & & 㽷投 & 15.1 & & 9.7 & & & 12.4 & & 6.2 & \\
\hline 9 & & 13.1 & & 3.0 & & $8 \underbrace{5}$ & 16.0 & & 8.3 & & 梁 & 13.9 & & 6.0 & \\
\hline 10 & 40 & 15.0 & & 6.5 & & & 16.9 & & 12.5 & & & 15.4 & & 8.0 & \\
\hline 11 & 投 & 10.1 & 11.3 & 3.2 & 4.3 & & 13.9 & 13.8 & 9.8 & 8.9 & $\alpha$ & 11.2 & 11.9 & 5.0 & 5.6 \\
\hline 12 & 胡 & 9.7 & & 4.2 & & 1000 & 12.6 & & 8.0 & & & 10.2 & & 4.3 & \\
\hline 13 & & 10.6 & & 4.2 & & 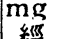 & 14.4 & & 7.8 & & & 12.5 & & 5.7 & \\
\hline 14 & 前 & 8.5 & & 2.7 & & 口 & 7.9 & & 6.0 & & 步 & 7.9 & & 4.0 & \\
\hline
\end{tabular}

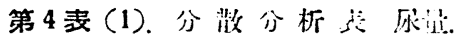

\begin{tabular}{|c|c|c|c|c|c|}
\hline 要因 & 禁動 & 自由度 & 不缩分散 & $F_{0}$ & F \\
\hline 級間 & 63.44 & 1 & 63.44 & 19.8 & $.01)=7.33$ \\
\hline 級內 & 38.28 & 12 & 3.19 & & \\
\hline
\end{tabular}

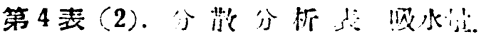

\begin{tabular}{|c|c|c|c|c|c|}
\hline 要因 & 樊動 & 自由周 & 不虫分散 & $F_{0}$ & $\mathrm{~F}$ \\
\hline 級間 & 183.61 & 1 & 183.61 & 22.61 & $>F_{12}^{1}(0.01)=7.33$ \\
\hline 級內 & 97.42 & 12 & 8.12 & & \\
\hline
\end{tabular}

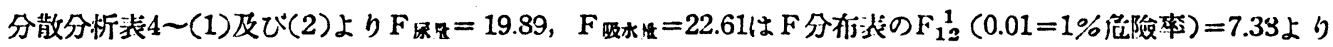

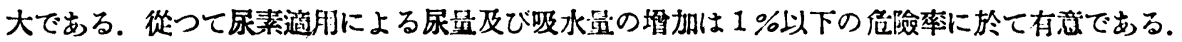

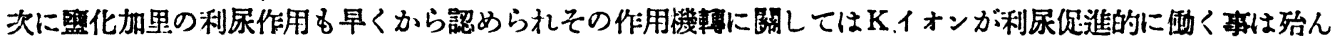

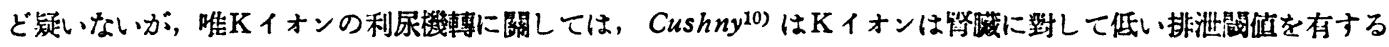

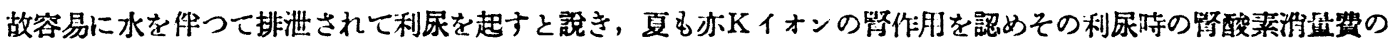

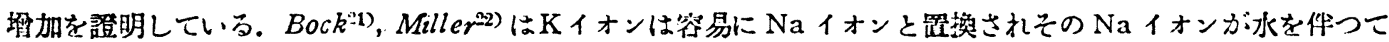

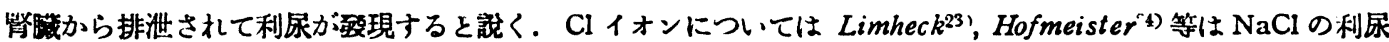
作用にういて分子量の小さなCIイオンが最も强い利尿作胢があると云い,その鿁明として尿中にはNaClの大监が

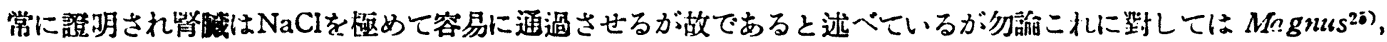

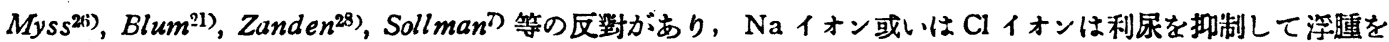

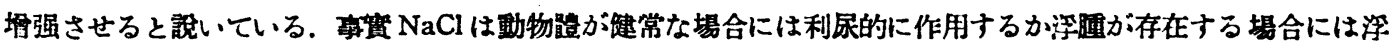
腫を增强させる事は臨林的に一致した意見である，元來Kイオンは細胞內に主として存在し $\mathrm{Na}$ イオンやClイオ ンは主として細胞外に存在ちると見られ大多数の學者の急見も一致しているが，最近放射性同位元兵を䏘、ての

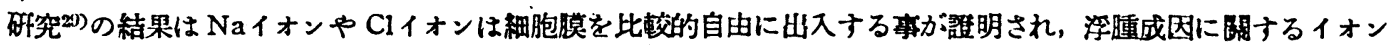

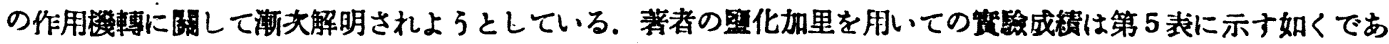
り，利局作用を認め得るが濑次隇少し逐には却つてそ尿を來子倾向がある. 


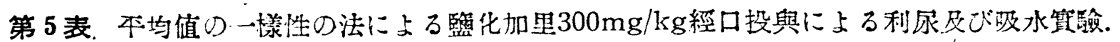

\begin{tabular}{|c|c|c|c|c|c|c|c|c|c|c|c|c|c|c|c|c|c|c|c|c|c|c|c|}
\hline \multirow{2}{*}{$\begin{array}{l}\bar{j} \\
\% \\
\text { テ } \\
\text { 番 } \\
\text { 號 }\end{array}$} & \multirow{2}{*}{$\begin{array}{l}\text { 藥 } \\
\text { 物 } \\
\text { 邂 } \\
\text { 用 } \\
\text { 區 } \\
\text { 分 } \\
\end{array}$} & \multicolumn{2}{|c|}{$\begin{array}{l}5 \text { 日間 } \\
\text { 本均尿 } \\
\text { (憘cc) }\end{array}$} & $\begin{array}{c}5 \text { 日間 } \\
\text { 尔均 } \\
\text { 吸水悬 } \\
\text { (cc) }\end{array}$ & \multirow{2}{*}{ 適用 } & \multicolumn{2}{|c|}{$\begin{array}{l}5 \text { 日間 } \\
\text { 平均尿 } \\
\text { 量 } \\
\end{array}$} & \multicolumn{2}{|c|}{$\begin{array}{c}5 \text { 日間本 } \\
\text { 均吸水量 } \\
\text { (cc) }\end{array}$} & \multirow{2}{*}{$\begin{array}{l}\text { 桬物 } \\
\text { 邀用 } \\
\text { 區分 }\end{array}$} & \multicolumn{2}{|c|}{$\begin{array}{l}5 \text { 日閴 } \\
\text { 里均尿 } \\
\text { 됸 }\end{array}$} & $\begin{array}{c}5 \text { 日問 } \\
\text { 本均 } \\
\text { 吸水毀 } \\
\text { (cc) } \\
\end{array}$ & \multirow{2}{*}{ 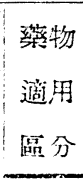 } & \multicolumn{2}{|c|}{ 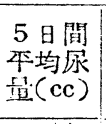 } & \multicolumn{2}{|c|}{$\begin{array}{c}5 \text { 日間 } \\
\text { 平均 } \\
\text { 吸水琶 } \\
\text { (cc) } \\
\end{array}$} & \multicolumn{3}{|c|}{ 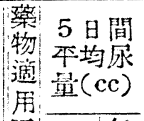 } & \multicolumn{2}{|l|}{$\begin{array}{c}5 \text { 日間 } \\
\text { 均吸水 } \\
\text { (cc) }\end{array}$} \\
\hline & & 每匹 & 群 & 每匹海 $^{\mid \text {每 }}$ & & 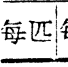 & 每群 & 每匹 & 每群 & & 每匹 & 铮 & 敏匹每 & & 每匹 & \begin{tabular}{|l|} 
每 \\
群
\end{tabular} & 每匹 & $\begin{array}{l}\text { 每 } \\
\text { 群 }\end{array}$ & & 每匹 & 每 & 每沉每视 & 椎 \\
\hline 1 & & 8.5 & & 2.0 & 監设 & 9.7 & & 3.1 & & 300 & 8.3 & & 1.6 & 300 & 7.7 & & 1.1 & & & 7.7 & & 0.1 & \\
\hline 2 & 菜 & 12.7 & & 5.1 & 化 & 13.5 & & 6.1 & & & 12.4 & & 5.1 & & 11.2 & & 4.4 & & & 11.3 & & 3.6 & \\
\hline 3 & & 8.6 & & 24 & 里 & 11.4 & & 5.8 & & 監 & 10.8 & & 4.4 & 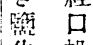 & 10.2 & & 3.7 & & & 11.1 & & 4.8 & \\
\hline 4 & & 10.9 & & 5.0 & $\begin{array}{l}\text { 每 } \\
\mathrm{kg}\end{array}$ & 12.0 & & 57 & & & 11.2 & & 5.8 & 化 & \begin{tabular}{l|l}
10.7 \\
\end{tabular} & & 4.5 & & & 10.7 & & 3.8 & \\
\hline 5 & 投 & 9.5 & 9.4 & $1.8^{2.6}$ & 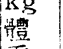 & 11.3 & 10.9 & 3.7 & 4 & & 9.8 & 9.8 & $2.6^{3.1}$ & 里 & 10.2 & 9.0 & 3.1 & & & 10.1 & 9.3 & 3.0 & 2.4 \\
\hline 6 & 與 & 6.9 & & 0.1 & 300 & 8.4 & & 1.3 & & $\begin{array}{l}\text { 每 } \\
k g\end{array}$ & 7.2 & & 0.4 & & 6.5 & & 0.1 & & & 6.2 & & 0.1 & \\
\hline 7 & & 9.3 & & 2.5 & $\mathrm{mg}$ & 11.0 & & 4.2 & & 能豊 & 9.3 & & 2.5 & 3 & 7.7 & & 1.0 & & & 8.4 & & 1.6 & \\
\hline 8 & & 8.8 & & 2.0 & 經 & 10.3 & & 3.5 & & 萑 & 9.5 & & 2.7 & & 8.0 & & 1.4 & & & 8.9 & & 2.2 & \\
\hline 9 & & & & 2.6 & & 9.3 & & 3.3 & & & 10.5 & & 3.3 & & 10.1 & & 0.7 & & & 10.9 & & 4. & \\
\hline 10 & & 10.5 & & 4.0 & & 10.8 & & 4.4 & & & 11.1 & & 5.5 & & 10.4 & & 3.6 & & & 10.8 & & 4.1 & \\
\hline 11 & 對 & 10.1 & & 2.9 & 對 & 10.7 & & 4.7 & & 湄 & 10.9 & & 4.6 & Le & 11.3 & & 4.8 & & & 11.4 & & 4.6 & \\
\hline 12 & & 10.1 & & 2.4 & & 11.2 & & 2.3 & & & 9.3 & & 2.5 & & 10.7 & & 3.8 & & & 11.2 & & 5.2 & \\
\hline 13 & & 11.5 & & $5.0^{2.7}$ & & 10.8 & 9.8 & 3.6 & 20 & & 9.8 & & $3.1^{2.9}$ & & 10.1 & 9.6 & 3.0 & & & 8.9 & 9.6 & 1.52 & 2.8 \\
\hline 14 & & 7.4 & & 1.0 & & 8.8 & & 1.7 & & & 8.3 & & 1.0 & & 8.0 & & 0.1 & & & 7.7 & & 1.0 & \\
\hline 15 & 沼 & 9.1 & & 2.0 & 㹦 & 8.6 & & 1.9 & & 照 & 8.4 & & $1 . t$ & 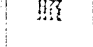 & 8.3 & & 1.6 & & & 8.9 & & 1.2 & \\
\hline 16 & & 8.3 & & 1.3 & & S.1; & & 1.1 & & & S.2 & & $1 . \overline{5}$ & & 7.9 & & 2.2 & & & 7.8 & & 0.8 & \\
\hline
\end{tabular}

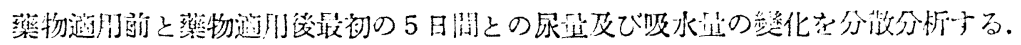

第 5 表 (1). 分教分析莸 水量.

\begin{tabular}{|c|c|c|c|c|c|}
\hline 要因 & 變動 & 自由度 & 不舅分教 & $F_{0}$ & F \\
\hline 級間 & 7.03 & 1 & 7.03 & 14.96 & $(0.01)=8.86$ \\
\hline 級內 & 6.57 & 14 & 0.47 & & \\
\hline
\end{tabular}

第 5 表 $(1)^{\prime}$. 分散 分析注 吸水至.

\begin{tabular}{|c|c|c|c|c|c|}
\hline 喓因 & 綮䙲 & 自由 & 僱分散 & $F_{0}$ & $\mathrm{~F}$ \\
\hline 級間 & 5.23 & 1 & 5.23 & $6.69)$ & $0.05)=4.60$ \\
\hline 級內 & 11.11 & 14 & 0.79 & & \\
\hline
\end{tabular}

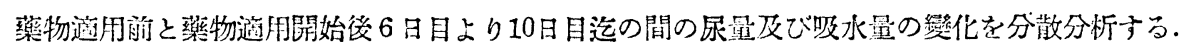

第 5 表 (2). 分散 分析表 尿量.

\begin{tabular}{|c|c|c|c|c|c|}
\hline 要因 & 鶖動 & 自由度 & 不源分散 & $F_{0}$ & $F$ \\
\hline 級間 & 0.68 & 1 & 0.68 & 0.8 & $.05)=4.60$ \\
\hline 級內 & 11.21 & 14 & 0.80 & & \\
\hline
\end{tabular}

第 5 表 $(2)^{\prime}$. 分散 分析注 吸水望.

\begin{tabular}{|c|c|c|c|c|c|}
\hline 要因 & 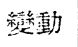 & 自皮度 & 不唯分散 & $\mathrm{F}_{0}$ & $\mathrm{~F}$ \\
\hline 級間 & 0.96 & 1 & 0.96 & $1.0<$ & $05)=4.60$ \\
\hline 級内 & 13.44 & 14 & 0.96 & & \\
\hline
\end{tabular}

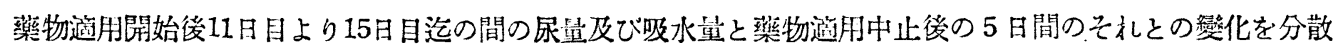
分析する.

第5 表 (3). 分散 分析表 尿量.

\begin{tabular}{|c|c|c|c|c|c|}
\hline 要因 & 禁動 & 自由度 & 不㴜分散 & $F_{0}$ & F \\
\hline 級間 & 0.57 & 1 & 0.57 & & $0.05)=4.60$ \\
\hline 級內 & 13.95 & 14 & . 1.- & & \\
\hline
\end{tabular}

第 5 表 $(3)^{\prime}$. 分散 分析表 吸水量.

\begin{tabular}{|c|c|c|c|c|}
\hline 要因 & 綮動 & 自由度 & 不偏分散 & $\mathrm{F}_{0}$ \\
\hline 級間 & 0.0006 & 1 & 0.0006 & $0.0004<\mathrm{F}_{14}{ }^{1}(0.05)=4.60$ \\
\hline 級內 & 22.04 & 14 & 1.43 & \\
\hline
\end{tabular}




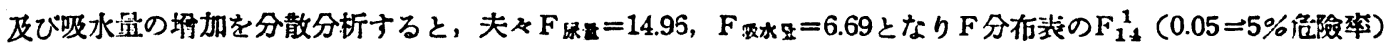

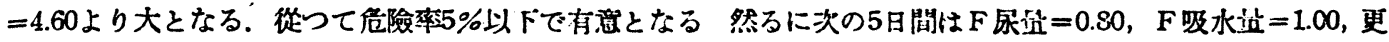

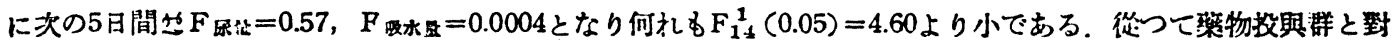

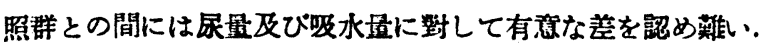

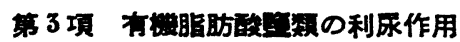

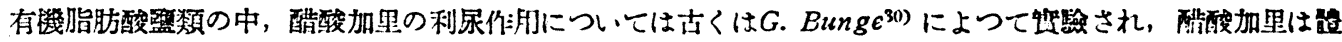

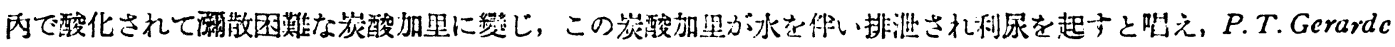

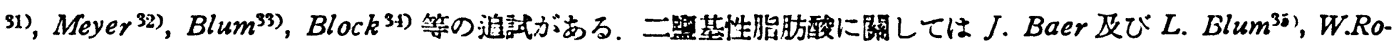

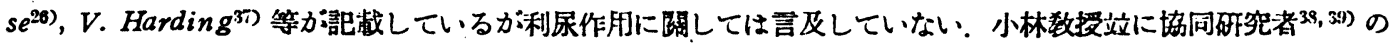

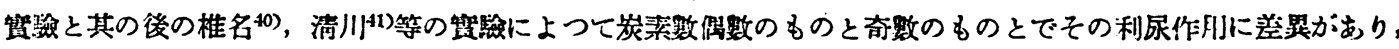
コルク酸, Sebazin-酸, Dydecandriarbon-酸に於て最も蔳明な事が分つた。 B. D. Baer2) ( Pentbarbital

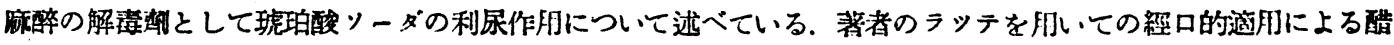

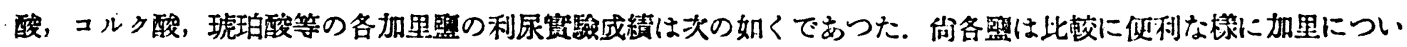
て賞语を使用した（第6〜12表參照）.

第 6 表. 本均值の一棬性の法に上る醋酸加里 $16 \mathrm{mg}$ 及び $80 \mathrm{mg} / \mathrm{kg}$ 經口投與に上万利尿及び吸水定验.

\begin{tabular}{|c|c|c|c|c|c|c|c|c|c|c|c|c|c|c|c|}
\hline \multirow{2}{*}{$\begin{array}{l}\text { ラッ } \\
\text { テ } \\
\text { 番號 }\end{array}$} & \multirow{2}{*}{$\begin{array}{l}\text { 䑁物 } \\
\text { 適用 } \\
\text { 品分 }\end{array}$} & \multicolumn{2}{|c|}{$\begin{array}{l}5 \text { 日間平均 } \\
\text { 尿量 (cc) }\end{array}$} & \multicolumn{2}{|c|}{$\begin{array}{c}5 \text { 日間平均 } \\
\text { 吸水望 }(\mathrm{cc})\end{array}$} & \multirow{2}{*}{$\begin{array}{l}\text { 县物 } \\
\text { 適用 } \\
\text { 茄分 }\end{array}$} & \multicolumn{2}{|c|}{$\begin{array}{l}5 \text { 日間平均 } \\
\text { 尿的 (cc) } \\
\end{array}$} & \multicolumn{2}{|c|}{$\begin{array}{l}5 \text { 日间平均 } \\
\text { 级水佔 }(\mathrm{cc})\end{array}$} & \multirow{2}{*}{ 適簿分 } & \multicolumn{2}{|c|}{$\begin{array}{l}5 \text { 日間平均 } \\
\text { 尿掊 (cc) }\end{array}$} & \multicolumn{2}{|c|}{$\begin{array}{c}\text { 5日間本均 } \\
\text { 吸水巷(cc) }\end{array}$} \\
\hline & & 每匹 & 每群 & 每匹 & 每群 & & 每匹 & 每群 & 每匹 & 每群 & & 每匹 & 每群 & 每匹 & 每群 \\
\hline 1 & & 12.0 & & 3.3 & & 腊經 & 11.5 & & 2.6 & & 强 & 10.5 & & 2.2 & \\
\hline 2 & 釉 & 11.4 & & 2.7 & & 醮口 & 11.4 & & 2.0 & & 策 & 11.5 & & 2.0 & \\
\hline 3 & 物 & 12.0 & & 2.4 & & 是舅 & 12.2 & & 2.5 & & & 11.8 & & 1.8 & \\
\hline 4 & 放 & 11.0 & 10.8 & 1.4 & 2.2 & 能 & 12.1 & 11.1 & 2.3 & 2.2 & (ti) & 12.7 & 10.9 & 3.3 & 2.2 \\
\hline 5 & 與 & 13.0 & & 4.4 & & 福 & 11.9 & & 3.5 & & is & 12.6 & & 3.4 & \\
\hline 6 & 前 & 7.9 & & 0.3 & & 近 & 9.2 & & 0.8 & & $T$ & 8.2 & & 0.9 & \\
\hline 7 & & 8.6 & & 1.0 & & $\mathrm{mg}$ & 9.3 & & 1.5 & & & 8.8 & & 1.5 & \\
\hline 8 & & 9.2 & & 1.9 & & 睲經 & 9.0 & & 1.6 & & 贲 & 8.9 & & 1.0 & \\
\hline 9 & 樂 & 10.4 & & 25 & & 酸口 & 12.1 & & 2.8 & & 4 法 & 11.5 & & 2.1 & \\
\hline 10 & 物 & 7.5 & & 0.3 & & 里與 & 8.7 & & 0.6 & & 投 & S.0 & & 0.6 & \\
\hline 11 & 投 & 9.7 & 10.4 & 2.4 & 2.1 & $\begin{array}{l}\text { 每 } \\
\mathrm{kg}\end{array}$ & 10.6 & 11.3 & 2.0 & 2.3 & 县 & 10.5 & 10.6 & 1.6 & 1.6 \\
\hline 12 & 與 & 121 & & 2.7 & & 䯏 & 13.2 & & 3.5 & & 中 & 10.5 & & 2.0 & \\
\hline 13 & 前 & 13.0 & & 3.0 & & 80 & 12.6 & & 2.9 & & 止 & 12.4 & & 1.8 & \\
\hline 14 & & 11.2 & & 1.7 & & $\mathrm{mg}$ & 13.2 & & 2.6 & & & 12.3 & $\checkmark$ & 2.2 & \\
\hline 15 & & 10.1 & & 1.5 & & & 9.9 & & 1.1 & & & S.3 & & 0.5 & \\
\hline 16 & 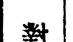 & 11.1 & . & 1.7 & & 缽 & 11.1 & & 1.6 & & 数 & 10.8 & & 1.8 & \\
\hline 17 & & 9.2 & & 1.6 & & & 9.2 & & 1.8 & & & 9.7 & & 1.5 & \\
\hline 18 & & 13.1 & 9.9 & 3.4 & 1.4 & & 12.9 & 9.8 & 3.2 & 1.4 & & 13.5 & 10.0 & 3.7 & 1.6 \\
\hline 19 & & 9.1 & & 0.7 & & & 8.6 & & 0.8 & & & 9.3 & & 1.0 & \\
\hline 20 & 照 & 8.9 & & 0.4 & & 㖹 & 9.4 & & 0.9 & & 昖 & 9.2 & & 0.9 & \\
\hline 21 & & 7.6 & & 0.3 & & & 7.5 & & 0.3 & & & 9.6 & & 1.6 & \\
\hline
\end{tabular}

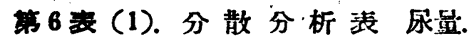

\begin{tabular}{|c|c|c|c|c|c|}
\hline 要因 & 枍的 & 自由度 & 不偏分散 & $\mathrm{F}_{\mathbf{0}}$. & F \\
\hline 級間 & 14.002 & 2 & 7.001 & 3.94 & $0.05)=3.55$ \\
\hline 級內 & 31.908 & 18 & 1.776 & & \\
\hline
\end{tabular}

第 6 表(1) (1)'. 䤃酸加里 $16 \mathrm{mg} / \mathrm{kg}$ 適用群 對炤群との间の分散分析表 尿典。

\begin{tabular}{l|c|c|c|l}
\hline \hline 要因 & 焚助 & 自由度不㴜分散 & Fo & F \\
\hline 級間 & 5.04 & 1 & 5.01 & $2.83<F_{18}^{1}(0.05)=4.41$ \\
䄲内 & 31.908 & 18 & 1.776 &
\end{tabular}


第 6 姜 $(1) \sim(2)^{\prime}$. 醋酸加里 $16 \mathrm{mg} / \mathrm{kg}$ 適用群と對炤群との間の分散分析蒜 尿量.

\begin{tabular}{|c|c|c|c|c|c|c|}
\hline 要 & 因 & 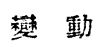 & 自由度 & 不偏分散 & Fo & $\mathrm{F}$ \\
\hline \multirow{2}{*}{\multicolumn{2}{|c|}{$\begin{array}{c}16 \mathrm{mg} \text { i } \mathrm{kg} \text { 適用群と的照群との間 } \\
\text { 級 }\end{array}$}} & 2.16 & 1 & 2.16 & \multirow{2}{*}{\multicolumn{2}{|c|}{$1.21<F_{18}^{1}(0.05)=4.41$}} \\
\hline & & 31.908 & 18 & 1.776 & & \\
\hline
\end{tabular}

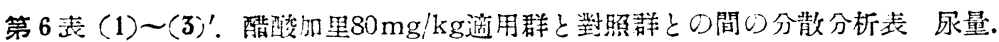

\begin{tabular}{|c|c|c|c|c|c|c|}
\hline 要 & 因 & 變 動 & 自由应 & 不洮分散 & $F_{0}$ & $\mathrm{~F}$ \\
\hline \multirow{2}{*}{\multicolumn{2}{|c|}{$\begin{array}{c}80 \mathrm{mg} / \mathrm{kg} \text { 道用群と對照群との間 } \\
\text { 級 }\end{array}$}} & 13.80 & 1 & 13.80 & \multirow{2}{*}{\multicolumn{2}{|c|}{$7.75>F_{18}^{1}(0.05)=4.41$}} \\
\hline & & 31.908 & 18 & 1.776 & & \\
\hline
\end{tabular}

第6表 (2). 分散 分析翡吸水量.

\begin{tabular}{|c|c|c|c|c|c|c|}
\hline 要 & 因 & 焚 動 & 自由度 & 不偏分散 & $F_{0}$ & $F$ \\
\hline 級 & 問 & 4.529 & 2 & 2.265 & & $55)=3.55$ \\
\hline 維 & 內 & 8.338 & 18 & 0.463 & & \\
\hline
\end{tabular}

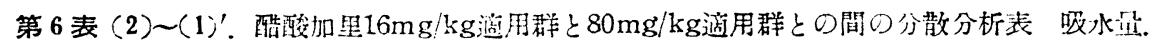

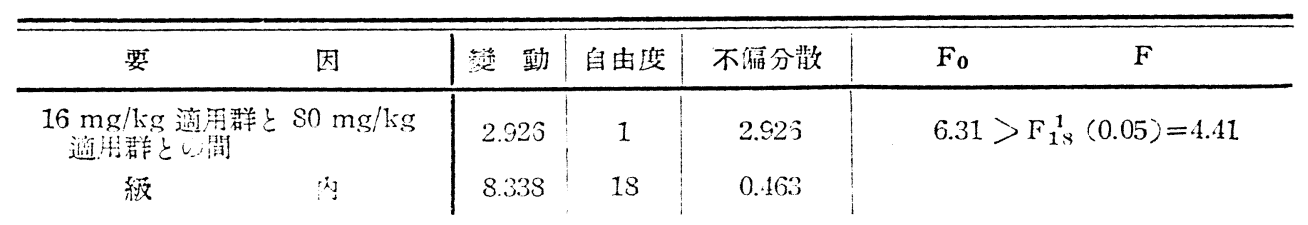

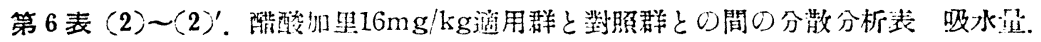

\begin{tabular}{|c|c|c|c|c|c|c|}
\hline 要 & 因 & 變 動 & 白由度 & 不偏分散 & $F_{0}$ & $\mathrm{~F}$ \\
\hline \multicolumn{2}{|c|}{$16 \mathrm{mg} / \mathrm{kg}$ 適用群と對照群との間 } & 005 & 1 & 0.06 & \multirow{2}{*}{\multicolumn{2}{|c|}{$0.1 \cdots<F_{18}^{1}(0.05)=4.41$}} \\
\hline 級 & 內 & 8.338 & 18 & 0.463 & & \\
\hline
\end{tabular}

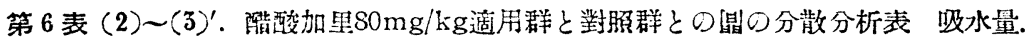

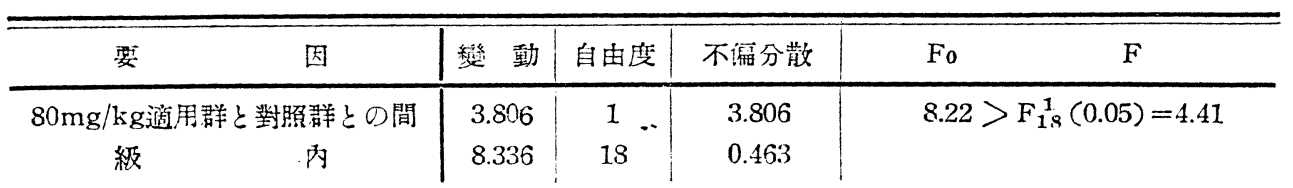

第 7 表. 平均值の一淡性の法による醋酸加里 $235 . \mathrm{mg} / \mathrm{kg}$ 經口投與による利尿及び吸水貫驗。

\begin{tabular}{|c|c|c|c|c|c|c|c|c|c|c|c|c|c|c|c|}
\hline \multirow{2}{*}{ 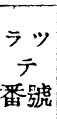 } & \multirow{2}{*}{ 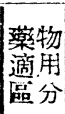 } & \multicolumn{2}{|c|}{$\begin{array}{l}6 \text { 日間平均 } \\
\text { 尔策 (cc) }\end{array}$} & \multicolumn{2}{|c|}{$\begin{array}{l}6 \text { 日间平均 } \\
\text { 吸水量( cc) }\end{array}$} & \multirow{2}{*}{$\begin{array}{l}\text { 藥物 } \\
\text { 避朋 } \\
\text { 區分 }\end{array}$} & \multicolumn{2}{|c|}{$\begin{array}{l}6 \text { 旦間平均 } \\
\text { 原量 (cc) }\end{array}$} & \multicolumn{2}{|c|}{$\begin{array}{l}6 \text { 日間平均 } \\
\text { 吸水量(cc) }\end{array}$} & \multirow{2}{*}{ 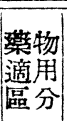 } & \multicolumn{2}{|c|}{$\begin{array}{l}6 \text { 間本均 } \\
\text { 尿量 (cc) }\end{array}$} & \multicolumn{2}{|c|}{$\begin{array}{c}6 \text { 日間本均 } \\
\text { 吸水量(cc) }\end{array}$} \\
\hline & & 每比 & 每群 & 每匹 & 每群 & & 每匹 & 每群 & 每远 & 每群 & & 每匹 & 每群 & 每区匹 & 每群 \\
\hline 1 & & 6.1 & & 0.7 & & 醋經 & 8.0 & & 4.3 & & 潑 & 6.3 & & 1.0 & \\
\hline 2 & 架 & 12.2 & & 11.8 & • & $\begin{array}{l}\text { 酸口 } \\
\end{array}$ & 20.5 & & 18.5 & & 勿 & 15.5 & & 11.8 & \\
\hline 8 & 物 & 15.7 & & 10.8 & & 里與 & 20.4 & & 13.3 & & & 15.3 & & 11.7 & \\
\hline 4 & 投 & 9.8 & 11.0 & 4.7 & 7.5 & $\begin{array}{l}\text { 每 } \\
\mathrm{kg}\end{array}$ & 14.3 & 14.6 & 9.5 & 11.5 & 與 & 9.0 & 11.4 & 5.0 & 7.2 \\
\hline 5 & 與 & 12.8 & & 11.0 & & 體 & 16.3 & & 16.0 & & 中 & 13.2 & & 9.2 & \\
\hline 6 & 前 & 10.7 & & 8.8 & & 車 & 12.3 & & 9.8 & & & 11.3 & & 7.3 & \\
\hline 7 & & 9.4 & & 4.5 & & $\mathrm{mg}$ & 10.4 & & 8:9 & & & 9.5 & & 4.3 & \\
\hline
\end{tabular}




\begin{tabular}{|c|c|c|c|c|c|c|c|c|c|c|c|c|c|c|c|}
\hline 8 & & 9.9 & & 7.2 & & & 7.2 & & 4.2 & & & 8.7 & & 4.3 & \\
\hline 9 & 對 & 10.6 & & 7.2 & & 對 & 9.3 & & 6.3 & & 對 & 10.7 & & 6.0 & \\
\hline 10 & & 7.9 & & 4.5 & & & 6.5 & & 5.0 & & & 7.8 & & 3.2 & \\
\hline 11 & & 12.1 & 11.2 & 13.5 & 8.8 & & 11.2 & 9.4 & 11.0 & 7.4 & & 13.2 & 10.9 & 10.3 & 6.6 \\
\hline 12 & & 13.0 & & 5.3 & & & 10.3 & & 5.0 & & & 12.7 & & 5.3 & \\
\hline 13 & 照 & 14.1 & & 13.3 & & 照 & 10.7 & & 11.8 & & 照 & 12.2 & & 10.2 & \\
\hline 14 & & 11.0 & & 10.3 & & & 10.3 & & 8.3 & & & 11.3 & & 7.0 & \\
\hline
\end{tabular}

第 7 表 (1). 分散 分析蒜 尿量.

\begin{tabular}{|c|c|c|c|c|}
\hline 要因 & 省索 動 & $\mid$ & 不㴼分散 & $\mathrm{F}_{0}$ \\
\hline 級間 & 368.229 & 1 & 368.2293 & $.2 \cdots>F_{12}^{1}(0.01)=7.33$ \\
\hline 級內 & 122.06 & 12 & 10.171 & \\
\hline
\end{tabular}

第 7 表 (2). 分散分析洼吸水量.

\begin{tabular}{|c|c|c|c|c|c|}
\hline 要因 & 愁般 動 & 自由 & 不雷分散 & $F_{0}$ & $F$ \\
\hline 級間 & 470.126 & 1 & 470.12 & 69. & $.01)=7.33$ \\
\hline 級內 & 98.983 & 12 & 8.249 & & \\
\hline
\end{tabular}

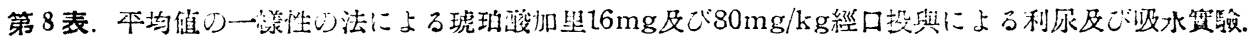

\begin{tabular}{|c|c|c|c|c|c|c|c|c|c|c|c|c|c|c|c|}
\hline \multirow{2}{*}{\begin{tabular}{c|} 
\\
$\%$ \\
テ \\
番號
\end{tabular}} & \multirow{2}{*}{ 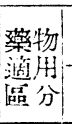 } & \multicolumn{2}{|c|}{ 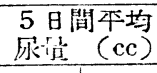 } & \multicolumn{2}{|c|}{ 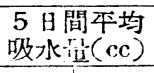 } & \multirow{2}{*}{$\begin{array}{l}\text { 蔡物 } \\
\text { 適用 } \\
\text { 点分 }\end{array}$} & \multicolumn{2}{|c|}{$\begin{array}{l}5 \text { 日間平均 } \\
\text { 㽷证 (cc) }\end{array}$} & \multicolumn{2}{|c|}{$\begin{array}{l}5 \text { 日閔平均 } \\
\text { 吸水坫 }(\mathrm{cc})\end{array}$} & \multirow{2}{*}{ 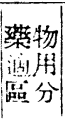 } & \multicolumn{2}{|c|}{$\begin{array}{l}5 \text { 日間平均 } \\
\text { 疗误 (cc) }\end{array}$} & \multicolumn{2}{|c|}{$\begin{array}{c}5 \text { 日間平均 } \\
\text { 吸水盐( }(\mathrm{cc})\end{array}$} \\
\hline & & 每匹 & 每群 & 每远 & 每群 & & 每匹 & 每群 & 每:匹 & 每群 & & 每匹 & 每群 & 每匹 & 年群 \\
\hline 1 & & 9.7 & & 2.7 & & 琥 $\mathrm{mg}$ & 10.0 & & 2.8 & & 㑠 & 10.0 & & 2.8 & \\
\hline 2 & 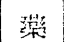 & 11.1 & & 4.1 & & 括 縞 & 11.7 & & 4.1 & & 10 & $11 . .4$ & & 3.9 & \\
\hline 3 & 物 & 11.0 & & 2.7 & & ti1 拉 & 11.2 & & 2.3 & & $+\infty$ & 12.0 & & 3.2 & \\
\hline 4 & 球 & 10.7 & 10.3 & 2.6 & $2 . j$ & & 10.6 & 10.4 & 2.5 & 2.6 & Sil & 11.0 & 10.6 & 2.7 & 2.7 \\
\hline 5 & 與 & 13.1 & & 4.1 & & $\mathrm{~kg}$ & 13.1 & & 4.0 & & 中 & 13.0 & & 4.1 & \\
\hline 6 & 解 & 7.6 & & 0.7 & & $\frac{1}{10}$ & 7.3 & & 0,5 & & 止 & 7.9 & & 0.7 & \\
\hline 7 & & 8.6 & & 1.3 & & 16 & 8.9 & & 1.8 & & & 8.6 & & 1.4 & \\
\hline 8 & & 7.4 & & 0.7 & & 琥 $\mathrm{mg}$ & 7.4 & & 0.5 & & 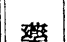 & 7.2 & & 0.4 & \\
\hline 9 & 㭞 & 9.7 & & 2.3 & & & 10.7 & & 2.6 & & 物 & 10.4 & & 2.0 & \\
\hline 10 & 物 & 7.3 & & 0.8 & & 加 投 & 7.7 & & 0.9 & & $\frac{1}{2}$ & 7.5 & & 1.0 & \\
\hline 11 & 投 & 7.6 & 9.7 & 1.3 & 2.4 & & 8.7 & 10.2 & 1.6 & 2.6 & 與 & 7.7 & 10.0 & 0.8 & 2.5 \\
\hline 12 & 與 & 13.0 & & 5.4 & & $\mathrm{~kg}$ & 13.5 & & 5.7 & & 中 & 13.3 & & 5.4 & \\
\hline 13 & 前 & 12.4 & & 4.6 & & 暜 & 12.2 & & 4.5 & & 止 & 13.0 & & 5.0 & \\
\hline 14 & & 10.7 & & 1.9 & & 80 & 11.4 & & 2.6 & & & 11.2 & & 2.8 & \\
\hline 15 & & 9.4 & & 1.6 & & & 9.4 & & 1.9 & & & 8.9 & & 1.5 & \\
\hline 16 & 對 & 10.9 & & 2.5 & & 数 & 10.6 & & 2.6 & & 對 & 11.1 & & 3.0 & \\
\hline 17 & & 8.9 & & 1.8 & & & 8.9 & & 1.9 & & & 9.2 & & 2.4 & \\
\hline 18 & & 12.5 & 9.2 & 4.6 & 1.9 & & 12.1 & 9.2 & 5.1 & 2.1 & & 13.1 & 9.2 & 6.0 & 2.2 \\
\hline 19 & & 7.4 & & 0.6 & & & 7.6 & & 0.7 & & & 7.1 & & 0.6 & \\
\hline 20 & 照 & 8.4 & & 1.2 & & 炤 & 8.9 & & 1.6 & & 照 & 8.2 & & 1.2 & \\
\hline 21 & & 7.1 & & 0.9 & & & 6.7 & & 0.4 & & & 6.6 & & 0.5 & \\
\hline
\end{tabular}

第 8 表 (1). 分 散 分 析 表 尿量.

\begin{tabular}{|c|c|c|c|c|c|}
\hline 要因 & 變 動 & \begin{tabular}{|l} 
自由 \\
度
\end{tabular} & 不编分散 & $F_{0}$ & F \\
\hline 級間 & 2.3107 & 2 & 1.1553 & $1.6 \cdot$ & $-F_{18}^{2}(0.05)=3.55$ \\
\hline 級內 & 12.6813 & 18 & 0.7045 & & \\
\hline
\end{tabular}

第 8 表 (2). 分散 分析茭 吸水量.

\begin{tabular}{|c|c|c|c|c|c|}
\hline 要因 & 榇動 & 自由度 & 不编分散 & $F_{0}$ & $\mathrm{~F}$ \\
\hline 級間 & 0.507 & 2 & 0.254 & 0.6. & $0.05)=3.55$ \\
\hline 級內 & 7.300 & 18 & 0.406 & & \\
\hline
\end{tabular}


第 9 表. 平均値の一㥞性の法に上万琥珀酸加里 $230 \mathrm{mg} / \mathrm{kg}$ 經口投與に上る利尿及び吸水筫驗。

\begin{tabular}{|c|c|c|c|c|c|c|c|c|c|c|c|c|c|c|c|}
\hline \multirow{2}{*}{ 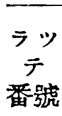 } & \multirow{2}{*}{ 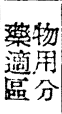 } & \multicolumn{2}{|c|}{$\begin{array}{l}5 \text { 日間本均 } \\
\text { 疗量 (cc) }\end{array}$} & \multicolumn{2}{|c|}{$\begin{array}{c}5 \text { 日間平均 } \\
\text { 吸水吉(cc) }\end{array}$} & \multirow{2}{*}{$\begin{array}{l}\text { 莭物 } \\
\text { 適用 } \\
\text { 區分 }\end{array}$} & \multicolumn{2}{|c|}{$\begin{array}{l}5 \text { 日間本均 } \\
\text { 㲾望 (cc) }\end{array}$} & \multicolumn{2}{|c|}{$\begin{array}{c}5 \text { 日間平均 } \\
\text { 吸水再(cc) }\end{array}$} & \multirow{2}{*}{$\begin{array}{l}\text { 悬物 } \\
\text { 適用 } \\
\text { 區分 }\end{array}$} & \multicolumn{2}{|c|}{ 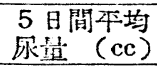 } & \multicolumn{2}{|c|}{$\begin{array}{c}5 \text { 日間平场 } \\
\text { 吸水量(cc) }\end{array}$} \\
\hline & & 每匹 & 每群 & 每匹 & 每群 & & 每迈 & 每群 & 每匹 & 每群 & & 每匹 & 每群 & 每匹 & 每群 \\
\hline 1 & & 8.7 & & 1.2 & & 琥經 & 9.0 & & 1.3 & & & 8.0 & & 1.0 & \\
\hline 2 & 樂 & 11.5 & & 2.6 & & 理口 & 12.2 & & 3.6 & & & 12.2 & & 2.8 & \\
\hline 3 & 物 & 9.5 & & 2.3 & & 加與 & 9.5 & & 1.6 & & 物 & 8.1 & & 1.1 & \\
\hline 4 & $t 几$ & 10.5 & & 2.3 & & 里 & 10.7 & & 2.7 & & 投 & 10.4 & & 2.5 & \\
\hline 5 & & 7.6 & 8.9 & 1.8 & 1.6 & $\mathrm{~kg}$ & 8.9 & 9.4 & 2.5 & 2.1 & 县 & 9.0 & 8.9 & 1.9 & 1.5 \\
\hline 6 & 與 & 6.3 & & 0.3 & & 體 & 6.0 & & 0.5 & & 中 & 6.4 & & 0.4 & \\
\hline 7 & 前 & 8.2 & & 1.1 & & 230 & 9.2 & & 2.6 & & & 8.8 & & 1.3 & \\
\hline 8 & & 8.6 & & 1.4 & & $\mathrm{mg}$ & 10.0 & & 2.2 & & II. & 8.3 & & 1.2 & \\
\hline 9 & & 9.5 & & 2.2 & & & 9.7 & & 1.8 & & & 9.0 & & 1.8 & \\
\hline 10 & 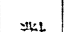 & 9.1 & & 1.2 & & $m_{i}$ & 8.9 & & 1.5 & & & 10.0 & & 2.3 & \\
\hline 11 & & 9.3 & & 1.9 & & & 9.2 & & 1.3 & & & 9.6 & & 1.8 & \\
\hline 12 & & 9.3 & & 1.9 & & & 9.4 & & 2.2 & & & 9.6 & & 2.1 & \\
\hline 13 & & 10.8 & 9.1 & 2.9 & 1.6 & & 11.1 & 9.1 & 3.0 & 1.6 & & 11.0 & 9.2 & 2.8 & 1.6 \\
\hline 14 & & 7.2 & & 0.5 & & & 6.9 & & 0.3 & & & 6.9 & & 0.5 & \\
\hline 15 & 照 & .9 .8 & & 1.9 & & 照 & 10.1 & & 1.8 & & 照 & 9.4 & & 1.1 & \\
\hline 16 & & 7.8 & & 0.4 & & : & 7.8 & & 0.6 & & & 7.8 & & 0.6 & \\
\hline
\end{tabular}

第 9 麦 (1). 分散分析注尿星.

\begin{tabular}{|c|c|c|c|c|c|}
\hline 姦因 & 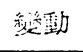 & 兒由度 & 不涪分渻 & $F_{0}$ & $\mathrm{~F}$ \\
\hline 級間 & 5.501 & 1 & 5.501 & 6.510 & $(0.05)=4.63$ \\
\hline 級內 & 11.829 & 14 & 0.845 & & \\
\hline
\end{tabular}

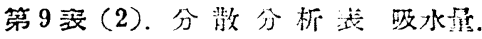

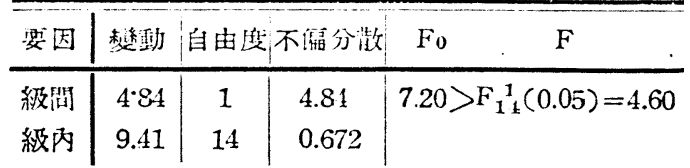

第10表. 本均值の一樣性の法によるコルク酸加里 $20 \mathrm{mg} / \mathrm{kg}$ 經口投與による利尿及び吸水贯驗.

\begin{tabular}{|c|c|c|c|c|c|c|c|c|c|c|c|c|c|c|c|}
\hline \multirow{2}{*}{$\begin{array}{c}\text { ラッ } \\
\text { テ } \\
\text { 番號 }\end{array}$} & \multirow{2}{*}{$\begin{array}{l}\text { 毗物 } \\
\text { 適用 } \\
\text { 區分 }\end{array}$} & \multicolumn{2}{|c|}{$\begin{array}{l}5 \text { 日間平均 } \\
\text { 尿量 (cc) }\end{array}$} & \multicolumn{2}{|c|}{$\begin{array}{l}5 \text { 日間平均 } \\
\text { 吸水量 }(\mathrm{cc})\end{array}$} & \multirow{2}{*}{$\begin{array}{l}\text { 桪物 } \\
\text { 燠用 } \\
\text { 㶾分 }\end{array}$} & \multicolumn{2}{|c|}{$\begin{array}{l}5 \text { 日間本均 } \\
\text { 尿䉅 (cc) }\end{array}$} & \multicolumn{2}{|c|}{$\begin{array}{c}5 \text { 日間本均 } \\
\text { 吸水至 }(\mathbf{c c})\end{array}$} & \multirow{2}{*}{ 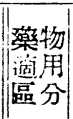 } & \multicolumn{2}{|c|}{$\begin{array}{l}\text { 5日間平均 } \\
\text { 尿量 (cc) }\end{array}$} & \multicolumn{2}{|c|}{$\begin{array}{c}5 \text { 日間本均 } \\
\text { 吸水量(cc) }\end{array}$} \\
\hline & & 每匹 & 每群 & 每匹 & . 每群 & & 每匹 & 每群 & 每匹 & 每群 & & 每匹 & 每群 & 每匹 & 每群 \\
\hline 1 & & 6.7 & & 0.7 & & 己經 & 6.8 & & 0.6 & & & 7.4 & & 0.4 & \\
\hline 2 & 苴 & 11.7 & & 3.8 & & $\begin{array}{c}n \square \\
n=0\end{array}$ & 11.7 & & 3.4 & & 菜 & 12.3 & & 3.1 & \\
\hline 3 & 物 & 8.4 & & 0.8 & & 酸與 & 7.3 & $\cdots$ & 0.6 & & 物 & 8.3 & & 0.7 & \\
\hline 4 & 投 & 9.1 & & 1.6 & & 妿 & 10.4 & & 1.2 & & 投 & 10.3 & & 1.3 & \\
\hline 5 & & 8.0 & 8.6 & 1.4 & 1.4 & 每 & 7.5 & 8.4 & 1.1 & 1.2 & 與 & 7.7 & 8.6 & 0.7 & 1.0 \\
\hline 6 & 與 & 6.0 & & 0.2 & & $\begin{array}{l}\mathrm{kg} \\
\text { 骴 }\end{array}$ & 5.8 & & 0.3 & & 中 & 6.2 & & 0.1 & \\
\hline 7 & 前 & 8.6 & & 0.5 & & 艊 & 7.9 & & 0.9 & & & 7.5 & & 0.5 & \\
\hline 8 & & 10.1 & & 1.8 & & $\begin{array}{l}20 \\
\mathrm{mg}\end{array}$ & 9.6 & & 1.5 & & II & 8.7 & & 1.5 & \\
\hline 9 & & 8.5 & & 0.8 & & & 8.0 & & 0.8 & & & 8.7 & & 1.4 & \\
\hline 10 & 對 & 7.3 & & 0 & & 数 & 8.5 & & 0.8 & & 数 & 8.9 & & 1.0 & \\
\hline 11 & & 7.8 & & 0.2 & & & 8.3 & & 0.3 & & & 7.1 & & 0.2 & \\
\hline 12 & & 10.4 & & 1.6 & & & 9.6 & & 1.1 & & & 10.2 & & 1.6 & \\
\hline 13 & & 10.9 & 8.8 & 3.6 & 1.0 & & 10.7 & 8.8 & 2.2 & 1.0 & & 11.1 & 9.2 & 25 & 1.2 \\
\hline 14 & & 6.9 & & 0.2 & & & 8.1 & & 0.8 & & & 7.4 & & 0.6 & \\
\hline 15 & 照 & 9.0 & & 0.7 & & 照 & 8.9 & & 0.9 & & 炤 & 11.4 & & 1.6 & \\
\hline 16 & & 9.5 & & 0.9 & & & 8.4 & & 1.0 & & & 8.4 & & 0.8 & \\
\hline
\end{tabular}


第10表 (1). 分散分析表 尿量.

\begin{tabular}{|c|c|c|c|c|c|}
\hline 要因 & 禁動 & 自由度 & 不搜分散 & $F_{0}$ & $\mathrm{~F}$ \\
\hline 級間 & 0.01 & 1 & 0.01 & 0.004 & $.05)=4.60$ \\
\hline 級內 & 25.05 & 14 & 2.08 & & \\
\hline
\end{tabular}

第10表 (2). 分散 分析泣 吸水量.

\begin{tabular}{|c|c|c|c|c|c|}
\hline 㛎因 & 戀勀 & 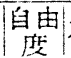 & 不溜分散 & $F_{0}$ & F \\
\hline 級間 & 0.25 & 1 & 0.25 & 0.54 & $(0.05)=4.60$ \\
\hline 級內 & 6.368 & 14 & 0.455 & & \\
\hline
\end{tabular}

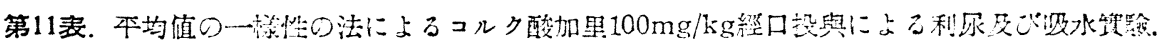

\begin{tabular}{|c|c|c|c|c|c|c|c|c|c|c|c|c|c|c|c|}
\hline \multirow{2}{*}{$\begin{array}{l}\overline{\text { ラ }} \\
\text { テ } \\
\text { 番號 }\end{array}$} & \multirow{2}{*}{ 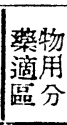 } & \multicolumn{2}{|c|}{$\begin{array}{l}5 \text { 日間平均 } \\
\text { 疗量 (cc) }\end{array}$} & \multicolumn{2}{|c|}{$\begin{array}{c}5 \text { 日間本均 } \\
\text { 吸水望(cc) }\end{array}$} & \multirow{2}{*}{$\begin{array}{l}\text { 炭物 } \\
\text { 適嵒分 }\end{array}$} & \multicolumn{2}{|c|}{$\begin{array}{l}5 \text { 日間平均 } \\
\text { 尿量 (cc) }\end{array}$} & \multicolumn{2}{|c|}{ 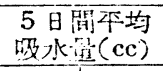 } & \multirow{2}{*}{ 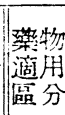 } & \multicolumn{2}{|c|}{$\begin{array}{l}5 \text { 日間平均 } \\
\text { 乍星 (cc) }\end{array}$} & \multicolumn{2}{|c|}{$\begin{array}{l}5 \text { 日間尔均 } \\
\text { 吸水基( }(\mathrm{cc})\end{array}$} \\
\hline & & 每匹 & 每群 & 每匹 & 每群 & & 每匹 & 每群 & 每匹 & 每群 & & 每匹 & 每群 & 每匹 & 每群 \\
\hline 1 & & 7.4 & & 0.3 & & 二經 & 8.6 & & 1.1 & & & 8.7 & & 0.8 & \\
\hline 2 & 息 & 12.3 & & 3.3 & & 只口 & 11.6 & & 3.2 & & 染 & 11.5 & & 3.6 & \\
\hline 3 & 物 & 8.3 & & 0.9 & & 酸與 & 11.1 & & 1.9 & & 物 & 9.5 & & 1.1 & \\
\hline 4 & the & 10.3 & & I. 1 & & 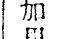 & 12.0 & & 2.0 & & 挆 & 10.5 & & 1.2 & \\
\hline 5 & & 7.7 & 8.6 & 1.4 & 1.1 & 知 & 8.5 & 9.4 & 1.7 & 1.6 & 與 & 7.6 & 8.9 & 1.2 & 1.3 \\
\hline 6 & 與 & 6.2 & & 0.2 & & $\mathrm{~kg}$ & 6.3 & & 0.7 & & 中 & 6.3 & & 0.3 & \\
\hline 7 & 前 & 7.5 & & 0.4 & & 塥 & 8.4 & & 0.7 & & & 8.2 & & 0.9 & \\
\hline 8 & & 8.7 & & 1.5 & & $\begin{array}{l}100 \\
\mathrm{mg}\end{array}$ & 8.7 & & 1.6 & & II & 8.6 & & 1.4 & \\
\hline 9 & & 8.7 & & 0.8 & & & 9.4 & & 1.1 & & & 9.6 & & 1.2 & \\
\hline 10 & $m_{1}$ & 8.9 & & 0.8 & & 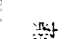 & 9.5 & & 1.0 & & 4 & 91 & & 1.1 & \\
\hline 11 & & 7.1 & & 0.3 & & & 8.9 & & 0.9 & & & 9.3 & & 1.3 & \\
\hline 12 & & 10.2 & & 1.7 & & & 9.6 & & 1.3 & & & 9.3 & & 1.2 & \\
\hline 13 & & 11.1 & 9.2 & 2.2 & 1.1 & & 10.7 & 9.1 & 2.3 & 1.0 & & 10.8 & 9.1 & 1.8 & 1.1 \\
\hline 14 & & 7.4 & & 0.5 & & & 6.9 & & 0.4 & & & 7.2 & & 0.4 & \\
\hline 15 & 踾 & 11.4 & & 1.6 & & 炤 & 9.8 & & 0.7 & & 照 & 9.8 & & 1.3 & \\
\hline 16 & & 8.4 & & 0.7 & & & 7.8 & & 0.5 & & & 7.8 & & 0.4 & \\
\hline
\end{tabular}

第11表 (1). 分散分析淙 尿量.

\begin{tabular}{|c|c|c|c|c|c|}
\hline 要因 & 禁動 & 自由度 & |不编分散| & $\mathrm{F}_{0}$ & $F$ \\
\hline 級間 & 9.00 & 1 & 9.00 & 4.68 & $>F_{14}^{1}(0.05)=4.60$ \\
\hline 級內 & 26.90 & 14 & 1.92 & & \\
\hline
\end{tabular}

第11麦 (2). 分散分析社 吸水橲.

\begin{tabular}{c|c|c|c|c}
\hline \hline 要因 & 秒動 & 自由度不编分散 & $F_{0}$ & $F$ \\
\hline 級間 & 3.150 & 1 & 3.150 & $9.72>F_{11}{ }^{1}(0.01)=8.86$ \\
級內 & 4.515 & 14 & 0.323 &
\end{tabular}

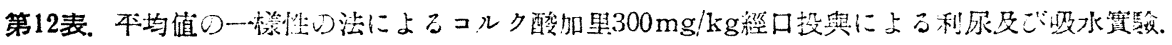

\begin{tabular}{|c|c|c|c|c|c|c|c|c|c|c|c|c|c|c|c|}
\hline \multirow{2}{*}{$\begin{array}{l}\overline{\text { ラッ }} \\
\overline{\text { テ }} \\
\text { 番號 }\end{array}$} & \multirow{2}{*}{ 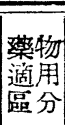 } & \multicolumn{2}{|c|}{$\begin{array}{l}5 \text { 日間本均 } \\
\text { 尿量 (cc) }\end{array}$} & \multicolumn{2}{|c|}{$\begin{array}{l}5 \text { 日間平均 } \\
\text { 吸水量 }(\mathrm{cc})\end{array}$} & \multirow{2}{*}{ 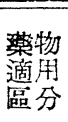 } & \multicolumn{2}{|c|}{$\begin{array}{l}5 \text { 日間平均 } \\
\text { 尿量 (cc) }\end{array}$} & \multicolumn{2}{|c|}{$\begin{array}{l}\text { 5日間本均 } \\
\text { 吸水量(cc) }\end{array}$} & \multirow{2}{*}{ 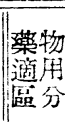 } & \multicolumn{2}{|c|}{$\begin{array}{l}5 \text { 日間平均 } \\
\text { 尿量 (cc) }\end{array}$} & \multicolumn{2}{|c|}{$\begin{array}{c}5 \text { 日間本均 } \\
\text { 吸水睡(ce) }\end{array}$} \\
\hline & & 每匹 & 每群 & 每匹 & 每群 & & 每匹 & 每群 & 每匹 & 每群 & & 每匹 & 每群 & 每匹 & 每群 \\
\hline 1 & & 7.9 & & 0.7 & & & 8.5 & & 0.1 & & & 8.1 & & 0.9 & \\
\hline 2 & 澲 & 12.1 & & 5.5 & & 對才 & 11.8 & & 4.2 & & 對 & 11.8 & & 4.2 & \\
\hline 3 & & 8.7 & & 1.6 & & & 8.9 & & 1.8 & & & 9.1 & & 2.8 & \\
\hline 4 & & 11.3 & & 5.6 & & & 12.0 & & 6.1 & & & 11.8 & & 5.2 & \\
\hline 5 & & 8.0 & 8.9 & 0.9 & 2.2 & & 7.7 & 9.0 & 0.7 & 2.0 & & 7.8 & 8.9 & 1.1 & 2.1 \\
\hline 6 & & 6.3 & & 0.1 & & & 7.2 & & 0.5 & & & 7.3 & & 0.7 & \\
\hline 7 & 照 & 7.8 & & 0.5 & & 炤 & 7.9 & & 0.7 & & 照 & 7.4 & & 0.5 & \\
\hline 8 & & 8.7 & & 2.9 & & & 8.3 & & 2.1 & & & 7.9 & & 1.5 & \\
\hline
\end{tabular}




\begin{tabular}{|c|c|c|c|c|c|c|c|c|c|c|c|c|c|c|c|}
\hline 9 & & 8.8 & & 2.1 & & 二經 & 9.6 & & 3.4 & & & 8.1 & & 1.0 & \\
\hline 10 & 案 & 9.0 & & 1.4 & & 只口 & 9.4 & & 2.4 & & 獎 & 8.1 & & 1.3 & \\
\hline 11 & 物。 & 7.1 & & 0.4 & & 酸與 & 9.3 & & 2.1 & & 物 & 8.0 & & 1.0 & \\
\hline 12 & 投 & 10.5 & & 5.4 & & $\begin{array}{l}\text { 妿 } \\
\text { 里 }\end{array}$ & 12.2 & & 6.7 & & 投 & 10.6 & & 5.1 & \\
\hline 13 & & 11.5 & 9.1 & 5.3 & 2.6 & 每 & 13.7 & 10.5 & 7.2 & 3.8 & 與 & 12.0 & 9.2 & 4.9 & 2.4 \\
\hline 14 & 與 & 7.1 & & 0.4 & & kg & 9.1 & & 1.8 & & 中 & 6.8 & & 0.3 & \\
\hline 15 & 前 & 11.4 & & 3.8 & & 電 & 13.0 & & 5.7 & & & 12.0 & & 5.2 & \\
\hline 16 & & 7.7 & & 2.0 & & $\begin{array}{l}300 \\
\mathrm{mg}\end{array}$ & 7.3 & & 1.0 & & I. & 7.6 & & 0.7 & \\
\hline
\end{tabular}

苏12装（1），分散分析表尿量。

\begin{tabular}{|c|c|c|c|c|c|}
\hline 要因 & 禁亜 & \begin{tabular}{|c|} 
自由 \\
度
\end{tabular} & 不偏分散 & $F_{0}$ & $F$ \\
\hline 級間 & 18.705 & 1 & 18.705 & 12.86 & $>F_{14}^{1}(0.01)=8.86$ \\
\hline 級內 & 21.385 & 14 & 1.456 & . & \\
\hline
\end{tabular}

第12表 (2). 分 散 分析表 吸水量.

\begin{tabular}{|c|c|c|c|c|c|}
\hline 要因 & 禁動 & $\mid$\begin{tabular}{|c|} 
自由 \\
度
\end{tabular} & 不保分散 & $F_{0}$ & $\mathrm{~F}$ \\
\hline 級间 & 31.922 & 1 & 31.922 & 20.85 & $>F_{14}^{1}(0.01)=8.86$ \\
\hline 級内 & 21.428 & 14 & 1.531 & & \\
\hline
\end{tabular}

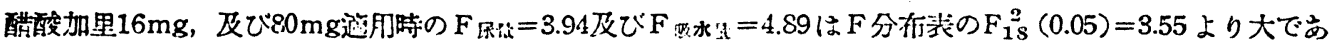

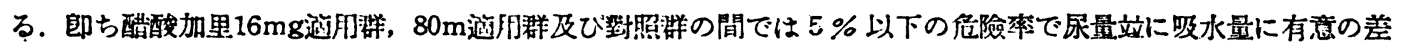

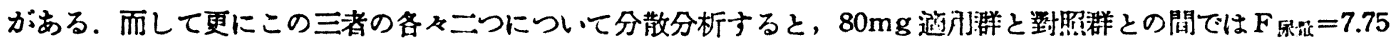

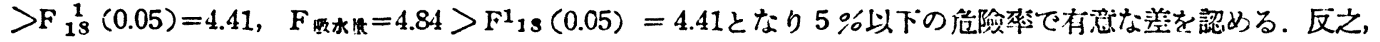

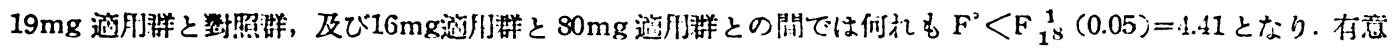

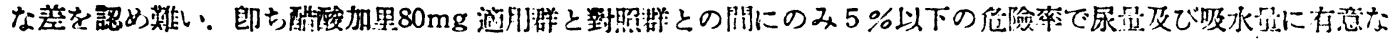
美在証めう。

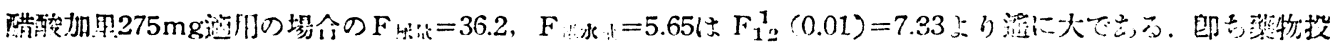

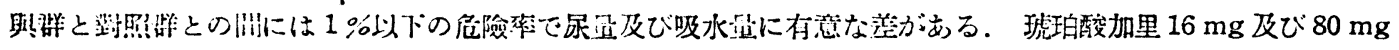

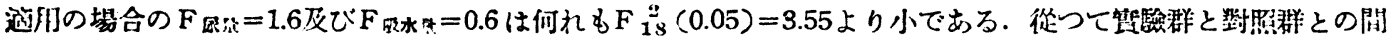

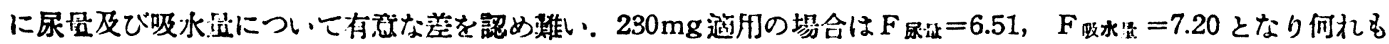

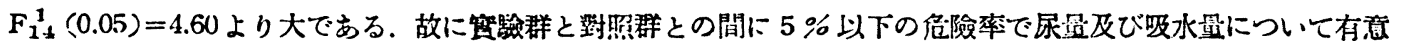
な差を認める。

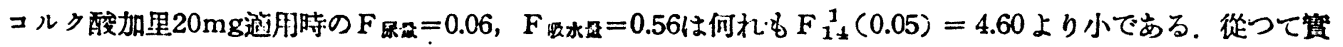

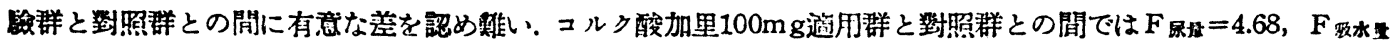
=9.72となるが之は何れも $F_{14}^{1}(0.05)=4.60$ より大である. 郎ち $5 \%$ 以下の危險率でその差は有意である. コル

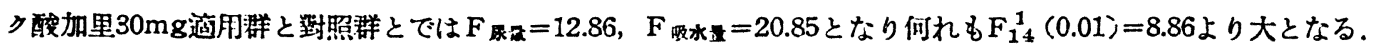

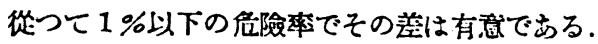

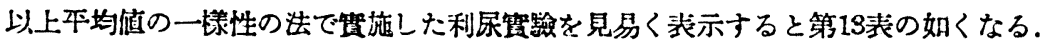

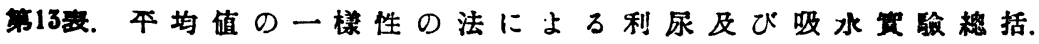

\begin{tabular}{|c|c|c|c|c|c|c|}
\hline 翡 & 品 & 名 & 资险計击法 & $\begin{array}{l}\text { 使用量 } \mathrm{mg} / \mathrm{kg} \\
\text { 鱾 投與 }\end{array}$ & - 利 尿 作 用 & 吸 水 \\
\hline 力 & $\begin{aligned}> & \pm 1 \\
& 11\end{aligned}$ & ע & $\begin{array}{c}\text { 平均值の一嵄性 } \\
\prime \prime\end{array}$ & $\begin{array}{l}10 \\
30\end{array}$ & $\begin{array}{c}\text { 認められない } \\
\prime \prime\end{array}$ & 堵娍かない。 \\
\hline & " & & " & 60 & " & $" \prime$ \\
\hline テ & オ & ע & " & 3,0 & " & $"$ \\
\hline 尿 & " & 秦 & $\begin{array}{l}\prime \prime \\
\prime \prime\end{array}$ & $\begin{array}{c}60 \\
1000\end{array}$ & 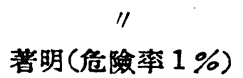 & 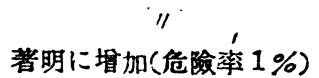 \\
\hline 聙 & 酸 & 里 & " & $\begin{array}{l}16 \\
80\end{array}$ & $\begin{array}{c}\text { 認められない } \\
\text { 輕度(危險率 } 5 \% \text { ) }\end{array}$ & 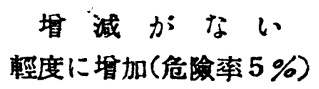 \\
\hline
\end{tabular}




\begin{tabular}{|c|c|c|c|c|}
\hline 醋 酸 加 里 & 平均値の一想性 & 235 & 诸明(结险率 $1 \%$ ) & 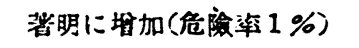 \\
\hline 琥珀酸加里 & " & 16 & 認められない & 坦 減 お:ない \\
\hline 11 & " & 80 & "1 & $\prime \prime$ \\
\hline " & " & 230 & 輼度(危險等 $5 \%$ ) & 輕度に坦加(危险辛 $5 \%$ ) \\
\hline コルク酸加里 & " & 20 & 铝められない & 坦 減 がない \\
\hline$" \prime$ & " & 100 & 競度（危險索 $5 \%$ ） & 签度に坦加（危險率 $1 \%$ ） \\
\hline$\prime \prime$ & "I & 300 & 㳣明(危險掌 $1 \%$ ) & 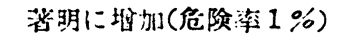 \\
\hline 䜿 化 加 里 & " & 300 & 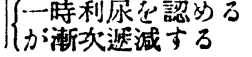 & 一時㙕加するか濑次瓝娍する \\
\hline
\end{tabular}

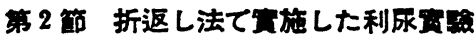

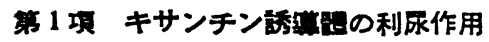

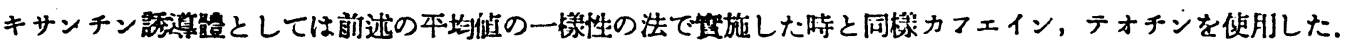
その成綪㝨第14，15表の如くでむつた。

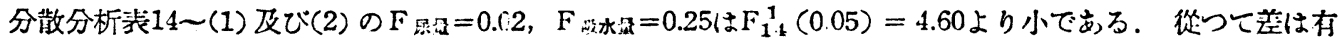

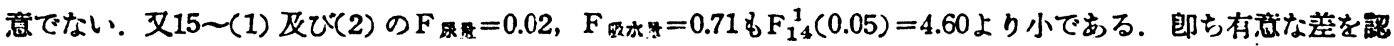

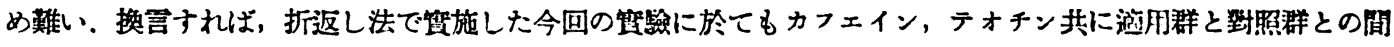

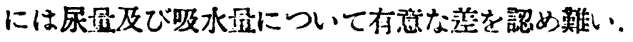

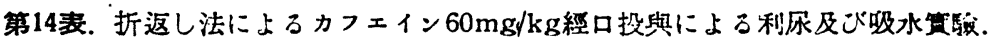

\begin{tabular}{|c|c|c|c|c|c|c|c|c|c|c|c|c|c|c|c|c|c|c|c|}
\hline $\begin{array}{c}\text { ラッ } \\
\text { テ }\end{array}$ & 弼物 & $\begin{array}{c}51 \\
\text { 尿 }\end{array}$ & $\begin{array}{l}\text { (j) } \\
\text { cc) }\end{array}$ & $\begin{array}{c}51 \\
\text { 吸水 }\end{array}$ & 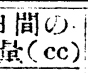 & 案物 & 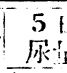 & $\begin{array}{l}\text { ial } \\
\text { cc) }\end{array}$ & $\begin{array}{r}5 \mathrm{1} \\
\text { 四水 }\end{array}$ & $\begin{array}{l}10 \\
(0) \\
\text { (c) }\end{array}$ & 䍒物 & $\begin{array}{l}51 \\
\text { 家 }\end{array}$ & $\begin{array}{l}\text { lui } \\
\text { cc) }\end{array}$ & $\begin{array}{r}51 \\
\quad 10\end{array}$ & $\begin{array}{l}(c) \\
(c)\end{array}$ & $a_{1}$ & & $a \cong t$ & 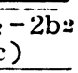 \\
\hline 番號 & 嗃監分分 & 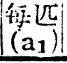 & 悔磁 & $\begin{array}{c}\pi=0 \\
\mid(a=)\end{array} \mid$ & 每群 & נin & $\begin{array}{l}i=1 \\
\left(b_{1}\right)\end{array}$ & 知群 & $\begin{array}{l}4 . \mathrm{g} \\
(\mathrm{b}:)\end{array}$ & 的程 & 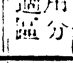 & $\begin{array}{l}1 ; 0 \\
\left(c_{1}\right)\end{array}$ & 聍船 & $\begin{array}{l}f=1 \\
\left(c_{2}\right)\end{array}$ & $\mathrm{A}_{j} \mathrm{j} \mathrm{Al}$ & 秘过 & 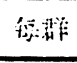 & 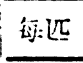 & 酻薜 \\
\hline $\begin{array}{l}1 \\
2 \\
3 \\
4 \\
5 \\
6 \\
7 \\
8\end{array}$ & 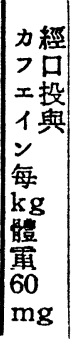 & $\left|\begin{array}{l}43.4 \\
57.2 \\
47.6 \\
52.6 \\
37.8 \\
31.4 \\
41.2 \\
43.0\end{array}\right|$ & 354.2 & $\begin{array}{r}10.9 \\
22.4 \\
9.5 \\
13.1 \\
7.4 \\
1.4 \\
11.0 \\
6.9\end{array}$ & 82.6 & $\begin{array}{l}\text { 藥 } \\
\text { 物 } \\
\text { 投 } \\
\text { 與 } \\
\text { 中 } \\
\text { 止 }\end{array}$ & $\mid \begin{array}{l}41.1 \\
57.0 \\
41.7 \\
53.6 \\
44.0 \\
34.1 \\
46.1 \\
39.9\end{array}$ & 357.5 & $\mid \begin{array}{r}7.6 \\
24.6 \\
6.4 \\
13.8 \\
8.3 \\
4.1 \\
12.8 \\
7.0\end{array}$ & 84.6 & 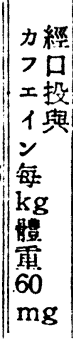 & $\begin{array}{l}40.0 \\
61.0 \\
40.6 \\
52.1 \\
44.5 \\
31.8 \\
44.0 \\
41.4\end{array}$ & 355.7 & \begin{tabular}{|r|}
6.7 \\
29.8 \\
8.3 \\
14.0 \\
9.1 \\
0.7 \\
12.2 \\
7.6
\end{tabular} & 88.4 & $\begin{array}{r}1.2 \\
4.2 \\
4.8 \\
-2.5 \\
-5.4 \\
-5.0 \\
-7.0 \\
4.6\end{array}$ & -5.1 & $\begin{array}{r}2.4 \\
3.0 \\
5.0 \\
-0.5 \\
-0.1 \\
-6.1 \\
-2.4 \\
0.5\end{array}$ & 1.8 \\
\hline $\begin{array}{c}9 \\
10 \\
11 \\
12 \\
13 \\
14 \\
15 \\
16\end{array}$ & $\begin{array}{l}\text { 畠 } \\
\text { 投 } \\
\text { 與 } \\
\text { 行 } \\
\text { は } \\
\text { な } \\
\text { い }\end{array}$ & $\begin{array}{l}47.8 \\
45.4 \\
46.7 \\
46.4 \\
53.8 \\
36.0 \\
49.1 \\
39.1\end{array}$ & 364.3 & \begin{tabular}{|r|}
13.6 \\
10.2 \\
16.5 \\
13.8 \\
24.6 \\
4.2 \\
13.0 \\
5.2
\end{tabular} & 101.1 & 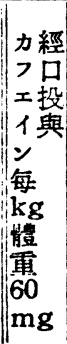 & $\mid \begin{array}{l}48.4 \\
44.4 \\
45.9 \\
47.2 \\
55.6 \\
34.5 \\
50.4 \\
38.9\end{array}$ & 365.3 & $\begin{array}{r}13.6 \\
10.6 \\
13.6 \\
15.8 \\
25.8 \\
1.5 \\
13.5 \\
6.3\end{array}$ & 100.7 & $\begin{array}{l}\text { 泶 } \\
\text { 物 } \\
\text { 投 } \\
\text { 與 } \\
\text { 中 } \\
\text { 止 }\end{array}$ & $\begin{array}{l}45.0 \\
50.1 \\
49.0 \\
47.9 \\
55.2 \\
34.7 \\
42.2 \\
39.2\end{array}$ & 363.3 & \begin{tabular}{|r|}
12.8 \\
15.4 \\
16.3 \\
16.6 \\
23.3 \\
4.3 \\
11.5 \\
8.0
\end{tabular} & 108.2 & $\begin{array}{r}-4.0 \\
6.7 \\
3.9 \\
-0.1 \\
-2.2 \\
1.7 \\
-9.5 \\
0.5\end{array}$ & -3.0 & $\begin{array}{r}-0.8 \\
4.4 \\
5.6 \\
-1.2 \\
-3.7 \\
5.5 \\
-2.5 \\
0.6\end{array}$ & 7.9 \\
\hline
\end{tabular}

第14表 (1). 分散分析表 尿量.

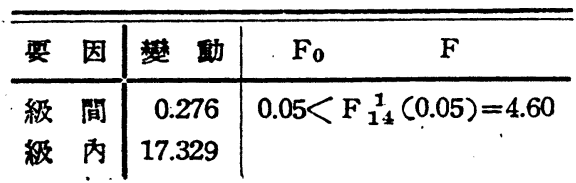

第14竞 (2). 分散分析表 吸水量。

\begin{tabular}{|c|c|c|c|}
\hline 要 因 & 变 助 & $F_{0}$ & $F$ \\
\hline 級 間 & 2.322 & $0.18<$ & $.05)=4.60$ \\
\hline 級 內 & 12.742 & & \\
\hline
\end{tabular}




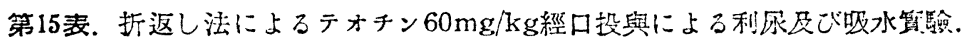

\begin{tabular}{|c|c|c|c|c|c|c|c|c|c|c|c|c|c|c|c|c|c|c|c|}
\hline \multirow{2}{*}{$\begin{array}{l}\text { ラッ } \\
\text { テ } \\
\text { 番㩆 }\end{array}$} & \multirow{2}{*}{$\begin{array}{l}\text { 滀物 } \\
\text { 適用 } \\
\text { 區分 }\end{array}$} & \multicolumn{2}{|c|}{$\begin{array}{l}5 \text { 日間 } \sigma) \\
\text { 永量 }(\mathrm{cc}) \\
\end{array}$} & \multicolumn{2}{|c|}{\begin{tabular}{|c|}
5 日間の \\
吸水量(cc)
\end{tabular}} & \multirow{2}{*}{ 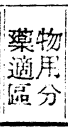 } & \multicolumn{2}{|c|}{$\begin{array}{l}5 \text { 日間o } \\
\text { 辰量(cc) }\end{array}$} & \multicolumn{2}{|c|}{$\begin{array}{c}5 \text { 日間 } 0 \\
\text { 吸水量( }(\mathrm{cc})\end{array}$} & \multirow{2}{*}{$\begin{array}{l}\text { 梁物 } \\
\text { 邀用 } \\
\text { 店分 }\end{array}$} & \multicolumn{2}{|c|}{ 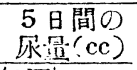 } & \multicolumn{2}{|c|}{$\begin{array}{c}5 \text { 日間の } \\
\text { 吸水量(cc) }\end{array}$} & \multicolumn{2}{|c|}{$\begin{array}{c}a_{1}+c_{1}-\angle b_{1} \\
(c c)\end{array}$} & \multicolumn{2}{|c|}{$\begin{array}{c}a g+c a-2 b \\
(c c) \\
\end{array}$} \\
\hline & & $\begin{array}{l}\text { 每匹 } \\
\left(a_{1}\right)\end{array}$ & 每群 & $\begin{array}{l}0 \\
(\mathrm{a} .2)\end{array}$ & 每萂 & & $\left(\mathrm{b}_{1}\right)$ & 每群 & 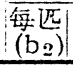 & 每群 & & $\begin{array}{l}\text { (6) } 10 \\
\left(c_{1}\right)\end{array}$ & 每群 & $\begin{array}{l}\text { 每 } \pi \\
(\mathrm{c} 2)\end{array}$ & 每群 & 每匹 & 每群 & 每匹 & 每群 \\
\hline 1 & & 41.9 & & 9.3 & & & 42.0 & & & & & 41.8. & & 6.9 & & -0.3 & & -1.0 & \\
\hline 2 & $\begin{array}{l}\text { テ經 } \\
才 口\end{array}$ & 61.9 & & 26.8 & & 樂 & 60.4 & & 23.0 & & テ䅔 & 60.5 & & 23.0 & & 1.6 & & & \\
\hline 3 & 手投 & 46.0 & & 10.7 & & 㸮 & 41.7 & & 7.4 & & 手地 & $\begin{array}{l}6 \\
\vdots\end{array}$ & & 8.8 & & 3.5 & & 4.7 & \\
\hline 4 & 舆 & 50.4 & & 12.5 & & 挆 & 54.0 & & 15.0 & & & 52.4 & & 16.1 & & -5.2 & & -1.4 & \\
\hline 5 & tif & 46.0 & 361 & 10.3 & 86.3 & 與 & 41.6 & 357. & 5.8 & 79.1 & $\begin{array}{l}\mathrm{zy} \\
\mathrm{kg}\end{array}$ & 43.8 & 359.4 & 8.2 & 3.8 & 6.6 & 5.6 & 6.9 & 12.1 \\
\hline 6 & 管 & 33.8 & & 2.5 & & 中 & 35.7 & & 3.0 & & 骨焉 & 34.8 & & 3.5 & & -2.8 & & & \\
\hline 7 & 60 & 40.8 & & 9.2 & & & 42.7 & & 11.6 & & 60 & $43 . S^{\prime}$ & & 12.0 & & -0.8 & & -2.0 & \\
\hline 8 & $\mathrm{mg}$ & 41.0 & & 5.0 & & 歨 & 39.7 & & 4.6 & & $\mathrm{mg}$ & 41.4 & & 5.3 & & 3.0 & & 1.1 & \\
\hline 9 & & 46.8 & & 10.2 & & & 47.8 & & 11.7 & & & 47.4 & & 9.8 & & -1.4 & & -3.4 & \\
\hline 10 & 藧 & 49.2 & & 19.9 & & 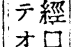 & 44.8 & & 16.1 & & 薬 & 49.9 & & 18.4 & & 9.5 & & & \\
\hline 11 & 坄 & 49.5 & & 21.3 & & 于落 & 47.9 & & 19.8 & & 物 & 17.6 & & 16.2 & & 1.3 & & -2.1 & \\
\hline 12 & 與 & 45.1 & & 15.5 & & 與 & 45.2 & & 15.6 & & 投 & 47.4 & & 19.0 & & 2.1 & & 3.3 & \\
\hline 13 & 行 & 55.6 & 367.1 & 27.0 & 119 & $\mathrm{~kg}$ & 54.8 & 368. & 27.6 & 118.4 & 蕑. & 56.0 & 373.7 & 25.6 & 8.4 & & 3.2 & -2.6 & 1.1 \\
\hline 14 & 岕 & 36.7 & & 4.3 & & 盟篮 & 35.5 & & 4.7 & & H & 34.4 & & 3.8 & & -1.9 & & -1.3 & \\
\hline 15 & $w$ & 46.3 & & 18.3 & & 60 & 52.8 & & 19.4 & & & 51.0 & & 20.2 & & -8.3 & & -0.3 & \\
\hline 16 & & 37.9 & & 3.0 & & $\mathrm{mg}$ & 39.0 & & 3.5 & & & 40.0 & & 5.4 & & -0.1 & & 1.4 & \\
\hline
\end{tabular}

第15表 (1). 分政分析尿量.

\begin{tabular}{|c|c|c|c|c|}
\hline 要 & 因 & 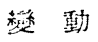 & $F_{0}$ & $\mathrm{~F}$ \\
\hline 嗮 & 間 & 0.360 & \multirow{2}{*}{\multicolumn{2}{|c|}{$0.018<F_{1.4}^{1}(0.05)=4.60$}} \\
\hline 約 & 内 & 19.471 & & \\
\hline
\end{tabular}

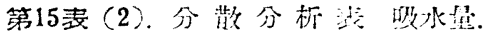

\begin{tabular}{|c|c|c|c|}
\hline 要 因 & 攀 動 & $F_{0}$ & $\mathrm{~F}$ \\
\hline 級 間 & 7.562 & $0.713<$ & $0.05)=4.60$ \\
\hline 紴 内 & 10.599 & & \\
\hline
\end{tabular}

\section{第 2 項 有機脂眆酸監類の利尿作用}

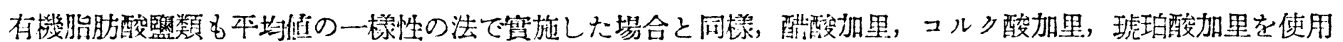
し，且，加里について當量となるようにして利尿作用の比較に便ならしめた，穴の证羷成績は第16〜18表の通り でまる。

第16麦. 折返し法に上る醋酸加里 $235 \mathrm{mg} / \mathrm{kg}$ 經口投與に上る利尿及び吸水質驗。

\begin{tabular}{|c|c|c|c|c|c|c|c|c|c|c|c|c|c|c|c|c|c|c|c|}
\hline \multirow{2}{*}{$\begin{array}{l}\text { ラッ } \\
\text { テ } \\
\text { 番號 } \\
\end{array}$} & \multirow{2}{*}{$\begin{array}{l}\text { 藥物 } \\
\text { 適覑 } \\
\text { 區分 }\end{array}$} & \multirow{2}{*}{\multicolumn{2}{|c|}{ 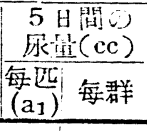 }} & \multirow{2}{*}{\multicolumn{2}{|c|}{ 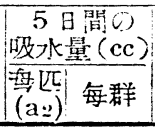 }} & \multirow{2}{*}{ 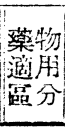 } & \multicolumn{2}{|c|}{$\begin{array}{l}5 \text { 日間( }) \\
\text { 疗量( }(\mathrm{cc}) \\
\end{array}$} & \multicolumn{2}{|c|}{$\begin{array}{c}5 \text { 日間0 } \\
\text { 吸水晋 (cc) }\end{array}$} & \multirow{2}{*}{ 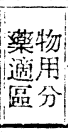 } & \multicolumn{2}{|c|}{ 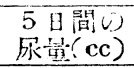 } & \multicolumn{2}{|c|}{$\begin{array}{c}5 \text { 日間 } \\
\text { 吸水量(cc) }\end{array}$} & \multicolumn{2}{|c|}{$\begin{array}{c}a_{1}+c_{1}-2 b_{1} \\
(c c)\end{array}$} & \multicolumn{2}{|c|}{$\begin{array}{c}\mathrm{a}_{2}+\mathrm{c}_{2}-2 \mathrm{~b}_{2} \\
(\mathrm{cc})\end{array}$} \\
\hline & & & & & & & 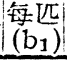 & 每群 & 每匹 & 每稀 & & 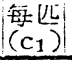 & 每群 & 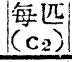 & 每群 & 每匹 & 每群 & 每匹 & 每群 \\
\hline 1 & 淇 & 75.5 & & 23.4 & & & 64.8 & & 15.1 & & 醌 & 73.9 & & 16.8 & & 19.8 & & 10.0 & \\
\hline 2 & 酸 & 48.6 & & 11.9 & & 䇾 & 48.6 & & 8.8 & & 酸 & 64.0 & & 16.5 & & 15.4 & & 10.8 & \\
\hline 3 & $\begin{array}{l}\text { 加 } \\
\text { 里 }\end{array}$ & 58.1 & & 9.7 & & & 53.9 & & 7.3 & & $\begin{array}{l}\text { 加 } \\
\text { 里 }\end{array}$ & 63.4 & & 15.4 & & 13.7 & & 10.5 & \\
\hline 4 & 每 & 44.1 & & 12.3 & & 物 & 38.4 & & 8.4 & & 䇘 & 48.0 & & 11.4 & & 15.3 & & 6.9 & \\
\hline 5 & $\begin{array}{c}\mathrm{kg} \\
\text { 骾 }\end{array}$ & 61.5 & & 23.5 & & 投 & 46.8 & & 14.4 & & $\begin{array}{c}\mathrm{kg} \\
\text { 此曹 }\end{array}$ & 54.8 & & 19.4 & & 22.7 & & 14.1 & \\
\hline 6 & 重 & 59.7 & 601.4 & 14.7 & 172.1 & 舉 & 50.2 & 554.1 & 12.1 & 146.7 & 奛 & 49.2 & 15.7 & 11.0 & 73.2 & 8.5 & 08.9 & 1.5 & 51.9 \\
\hline 7 & $\begin{array}{l}235 \\
\mathrm{mg}\end{array}$ & 60.9 & & 11.8 & & & 60.4 & & 15.3 & & $\begin{array}{l}235 \\
\mathrm{mg}\end{array}$ & 65.6 & & 19.2 & & & & & \\
\hline 8 & 經 & 63.0 & & 9.6 & & 中 & 66.4 & & 14.4 & & 經 & 60.2 & & 11.2 & & -9.6 & & - 8.0 & \\
\hline 9 & $\begin{array}{c}\text { 口 } \\
\text { 投 }\end{array}$ & 74.6 & & 31.8 & & 止 & 73.0 & & 31.2 & & $\begin{array}{c}\text { 口 } \\
\text { 投 }\end{array}$ & 70.4 & & 26.1 & & -1.0 & & -4.5 & \\
\hline 10 & 與 & 55.4 & & 23.4 & & & 51.6 & & 19.7 & & 與 & 66.2 & & 26.2 & & 18.4 & & 10.2 & \\
\hline
\end{tabular}




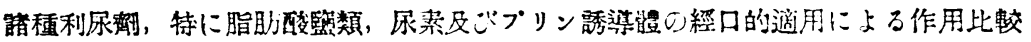

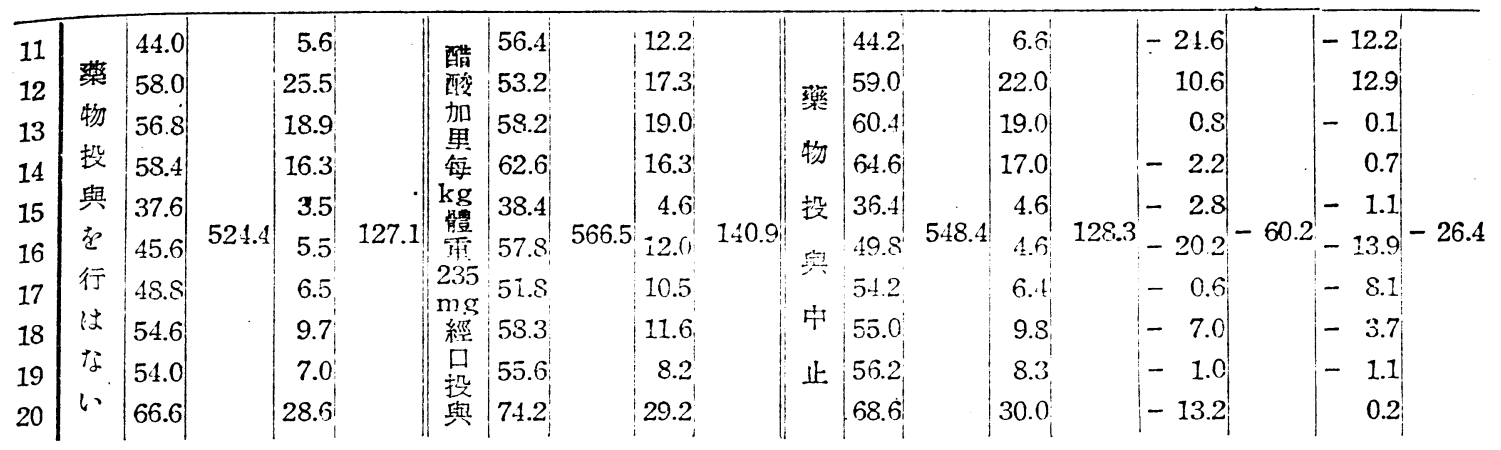

第16表(1). 分散 分析表 疗量.

\begin{tabular}{|c|c|c|}
\hline 要 因 & 禁 動 & $F_{0}$ \\
\hline 絲 間 & 1429.7 .1 & $13.42>F_{18}^{1}(.0 .01)=8.29$ \\
\hline 級 內 & 106.549 & \\
\hline
\end{tabular}

第1E表 (2). 分散分析堘吸水量.

\begin{tabular}{|c|c|c|c|}
\hline 要 因 & 和愁 期 & $F_{0}$ & $F$ \\
\hline 政 & $30 \div .54 .1$ & 5.43 & $.05)=1.41$ \\
\hline 級 内 & 56.426 & & \\
\hline
\end{tabular}

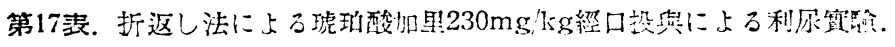

\begin{tabular}{|c|c|c|c|c|c|c|c|c|c|c|c|}
\hline \multirow{2}{*}{ 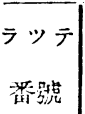 } & \multirow{2}{*}{$\begin{array}{l}\text { 萖物做 } \\
\text { 用區分 }\end{array}$} & \multicolumn{2}{|c|}{ 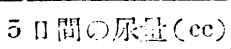 } & \multirow{2}{*}{ 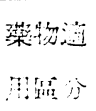 } & \multicolumn{2}{|c|}{ 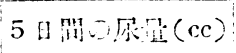 } & \multirow{2}{*}{ 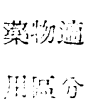 } & \multicolumn{2}{|c|}{ 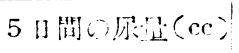 } & \multicolumn{2}{|c|}{$a+c-2 b(c c)$} \\
\hline & & 隹型( & 辞 教 & & 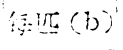 & 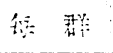 & & 稌西(c) & fif & 锊 匹 & 程 帮: \\
\hline 1 & 琥 & 68.6 & & & 6.5 .6 & & 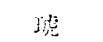 & $6 \cdot 1.3$ & & 1.7 & \\
\hline 2 & $x_{1}^{\prime \prime}$ & 69.2 & & 衙 & 63.0 & & 1 & 65.1 & & 3.5 & \\
\hline 3 & 批 & 57.3 & & & 54.4 & & tin & 63.5 & & 12.0 & \\
\hline 4 & 揖 & 56.0 & & 物 & 59.0 & & $\sqrt{1 !}$ & 59.8 & & -2.2 & \\
\hline 5 & $\mathrm{~kg}$ & 70.8 & & 投 & 65.0 & & $\mathrm{~kg}$ & 72.4 & & 13.2 & \\
\hline 6 & 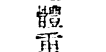 & 46.6 & 637.3 & 與 & 45.8 & 621.6 & 筁 & 53.8 & 644.3 & 8.8 & 38.4 \\
\hline 7 & 230 & 58.6 & & & 64.8 & & 230 & 62.7 & & -8.3 & \\
\hline$\dot{8}$ & $\mathrm{mg}_{\text {經 }}$ & 59.4 & & 中 & 55.6 & & $\mathrm{mg}$ & 62.0 & & 10.2 & \\
\hline 9 & 口 & 76.0 & & 止 & 75.2 & & 盗 & 67.6 & & -6.8 & \\
\hline 10 & 捣 & 74.8 & & & 73.2 & & $\begin{array}{l}\text { 投 } \\
\text { 與 }\end{array}$ & 72.8 & & 1.2 & \\
\hline 11 & & 55.6 & & 琥 & 62.8 & & & 62.0 & & -8.0 & \\
\hline 12 & 樂 & 61.8 & & 珀 & 61.4 & & 蒙 & 60.8 & & -0.2 & \\
\hline 13 & 物 & 76.6 & & ti!! & 79.2 & & & 76.6 & 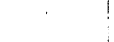 & -5.2 & \\
\hline 14 & 投 & 62.6 & & 晆 & 72.0 & & 物 & 72.0 & & -9.4 & \\
\hline 15 & 與 & 33.8 & & k & 46.8 & & 投 & 46.0 & & -13.8 & \\
\hline 16 & p & 53.2 & 612.8 & 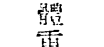 & 52.6 & 654.6 & 與 & 58.6 & 663.1 & 6.0 & -33.3 \\
\hline 17 & 行 & 59.2 & & 230 & 64.0 & & & 63.7 & & -5.1 & \\
\hline 18 & は & 72.8 & & $\operatorname{mg}_{\text {經 }}$ & 67.8 & & 中 & $: 73.4$ & & 10.6 & \\
\hline 19 & な & 62.0 & & 签 & 68.0 & & 止 & 72.8 & & -1.2 & \\
\hline 20 & い & 75.2 & & 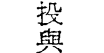 & 80.0 & & & 77.8 & & -7.0 & \\
\hline
\end{tabular}

第17表(1). 分散分析表尿量.

\begin{tabular}{|c|c|c|c|c|}
\hline 要 & 因 & 尜 動 & $\mathrm{F}_{0}$ & $F$ \\
\hline $\begin{array}{l}\text { 級 } \\
\text { 級 }\end{array}$ & $\begin{array}{l}\text { 閪 } \\
\text { 內 }\end{array}$ & $\begin{array}{r}2570.40 \\
564.62\end{array}$ & 4.55 & $=4.41$ \\
\hline
\end{tabular}




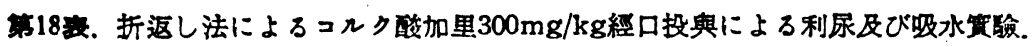

\begin{tabular}{|c|c|c|c|c|c|c|c|c|c|c|c|c|c|c|c|c|c|c|c|}
\hline \multirow{2}{*}{$\begin{array}{c}7 \% \\
\bar{F} \\
\text { 委號 }\end{array}$} & \multirow{2}{*}{ 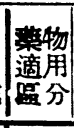 } & \multirow{2}{*}{\multicolumn{2}{|c|}{ 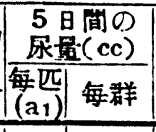 }} & \multirow{2}{*}{\multicolumn{2}{|c|}{ 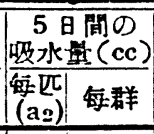 }} & \multirow{2}{*}{ 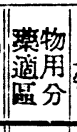 } & \multicolumn{2}{|c|}{$\begin{array}{l}5 \text { 日间の } \\
\text { 泉量(cc) } \\
\end{array}$} & \multicolumn{2}{|c|}{$\begin{array}{c}5 \text { 日間 } 9 \\
\text { 吸水量 (cc) }\end{array}$} & \multirow{2}{*}{ 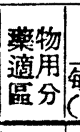 } & \multicolumn{2}{|c|}{ 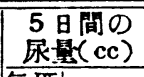 } & \multicolumn{2}{|c|}{$\begin{array}{c}5 \text { 日間 } 9 \\
\text { 吸水量(cc) }\end{array}$} & \multicolumn{2}{|c|}{$\begin{array}{c}a_{1}+c_{1}-2 b_{1} \\
(c c)\end{array}$} & \multicolumn{2}{|c|}{$\begin{array}{c}a+c_{2}-2 b^{2} \\
(c c)\end{array}$} \\
\hline & & & & & & & $\left|\begin{array}{l}\mid \pi \\
\left(b_{1}\right)\end{array}\right|$ & 每群 & $\left.\mid \begin{array}{l}-\pi \\
\left(b_{2}\right)\end{array}\right)$ & 每群 & & $\left|\begin{array}{|l|}\mid \mathbf{R}^{-} \\
\left(c_{1}\right)\end{array}\right|$ & 每群 & $\mid \begin{array}{l}\text { (每行 } \\
\left(\mathbf{c}_{2}\right)\end{array}$ & 每群 & 每匹 & 每群 & 每匹 & 每群 \\
\hline 1 & & 57.2 & & 21.9 & & & 52.8 & & $\mid 15.5$ & & 二投 & 54.2 & & 16.8 & & 5.8 & & 7.7 & \\
\hline 2 & & 72.8 & & 35.7 & & & 69.3 & & 34.1 & & $几$ 與 & 67.8 & & 30.6 & & 2.0 & & -0.9 & \\
\hline 3 & 酸 & 56.7 & & 20.6 & & & 53.5 & & 17.1 & & 酸 & 50.6 & & 15.6 & & 0.3 & & 2.0 & \\
\hline 4 & th & $\mid 49.8$ & & $\mid 15.4$ & & 物 & 51.7 & & $\mid 13.9$ & & $1 \pi$ & 55.1 & & $\mid 18.6$ & & 1.5 & & 6.2 & \\
\hline 5 & 量 & 62.5 & & 24.0 & 2000 & 投 & 58.9 & & 21.7 & 1045 & 海 & 61.9 & 599 & 29.1 & $15 ?$ & 6.6 & 260 & 9.7 & \\
\hline 6 & $\mathrm{~kg}$ & 84.9 & 599.8 & 37.2 & 209.9 & 與 & $87.0 \mid$ & 580.6 & 36.6 & 194.5 & $\mathrm{~kg}$ & 85.3 & 599. & 36.2 & 215.2 & -3.8 & 26.0 & 0.2 & 36. \\
\hline 7 & tis & 56.6 & & 15.5 & & & 51.2 & & 11.7 & & $\frac{68}{10}$ & 51.0 & & $\mid 11.6$ & & 5.2 & & 3.7 & \\
\hline 8 & 300 & 45.3 & & 7.0 & & 中 & 46.9 & & 10.8 & & 300 & 53.9 & & 14.8 & & 5.4 & & 0.2 & \\
\hline 9 & 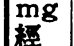 & 59.3 & & $|17.9|$ & & 止 & 61.0 & & 19.2 & & 經 & 64.2 & & 26.5 & & 1.5 & & 6.0 & \\
\hline 10 & 管 & $|54.7|$ & & $|13.7|$ & & & 54.3 & & $|13.9|$ & & 筎 & 55.4 & & 15.4 & & 1.5 & & 1.3 & \\
\hline 11 & & 9.6 & & 13.0 & & & 55.8 & & 15.0 & & & 56.5 & & 16.8 & & -5.5 & & -0.2 & \\
\hline 12 & 案 & 1.7 & & 23.7 & & & 64.0 & & 23.8 & & 棐 & 61.7 & & 22.4 & & -1.6 & & -1.5 & \\
\hline 13 & 物 & 53.8 & & 17.3 & & 西 & 54.3 & & 16.8 & & & 57.2 & & 18.0 & & 2.4 & & 1.7 & \\
\hline 14 & 投 & 0.4 & & 23.5 & & 10 & 62.2 & & 26.2 & & 物 & 63.8 & & 24.2 & & -0.2 & & -4.7 & \\
\hline 15 & 與 & 59.0 & & $\mid 19.1$ & & 19 & 64.0 & & $|25.4|$ & & 投 & 64.6 & & $\{2.0 \mid$ & & -4.4 & & -9.7 & \\
\hline 16 & 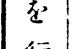 & 54.6 & 553.2 & 16.3 & 172 & $\mathrm{~kg}$ & 56.2 & 579. & 18.5 & $1 \subseteq 5.3$ & 战 & 56.2 & 580.6 & 16.7 & 184.4 & -1.6 & -25.0 & -4.0 & -33 \\
\hline 17 & 行 & 4.2 & & 228 & & 䯈 & 70.1 & & $2 \varsigma .7$ & & & 70.2 & & 28.8 & & -5.8 & & -7.8 & \\
\hline 18 & 织 & 31.6 & & 0.5 & & 300 & 33.2 & & 1.5 & & 中 & 31.8 & & 0.51 & & -3.0 & & -2.0 & \\
\hline 19 & 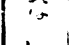 & 50.7 & & 12.4 & & $k$ & 53.8 & & 14.8 & & 止 & 54.4 & & 12.8 & & -2.5 & & -4.4 & \\
\hline 20 & い & 64.6 & & 23.7 & & 口 & 65.8 & & 23.6 & & & 64.2 & & 22.2 & & -2.8 & & -1.3 & \\
\hline
\end{tabular}

第18表 (1)。分散分析步尿量.

\begin{tabular}{|c|c|c|}
\hline 要 因 & 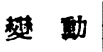 & $F_{0}$ \\
\hline 級 間 & 130.05 & $16.05>F_{18}^{1}(0.01)=8.28$ \\
\hline 級 內 & 8.102 & \\
\hline
\end{tabular}

第18表 (2). 分散分析表吸水量.

\begin{tabular}{lc|r|cc}
\hline \hline 要 & 因 & Fo & Fo & \multicolumn{1}{c}{$F$} \\
\hline 級 & 間 & 244.301 & $19.44>F_{18}^{1}(0.01)=8.28$ \\
級 & 內 & 12.561 & &
\end{tabular}

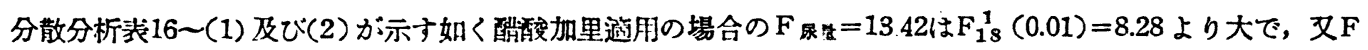

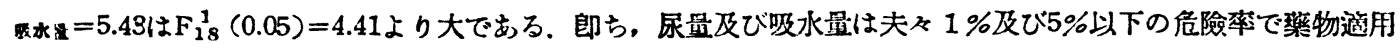

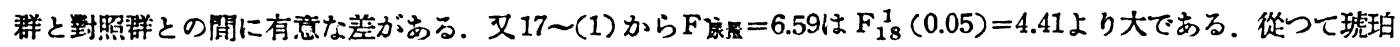
酸加里通䶺群之對照群との間にも5\%以下の危险率で尿量に有意な差を認める.

コルク酸加里は分散分析表18〜(1)及び(2)の如く $F_{\text {是量 }}=16.05, F_{\text {吸水 }}=19.44$ は何れる $F_{18}^{1}(0.01)=8.28$ より 造に大きい，換言すれば、ニルク酸加里遒用群と對照群との尿量及で吸水量の差は，1\%以下の危險率で有意で ある.

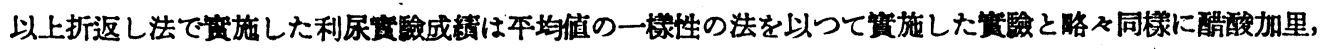
コルク酸加里に颓明な利尿を認め, 琥珀酸加里に輕度の利尿を證明した。

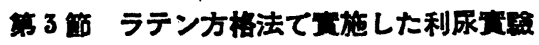

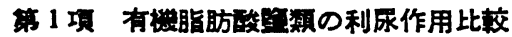

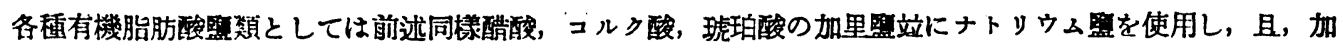
里及でナトリッムについて常盗となるようにして相互間の利尿作用を比較した，その成樍は第19，20表の通りで ある。 


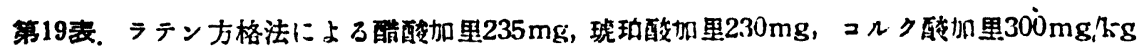
經口投與による利尿及び吸水安欲。

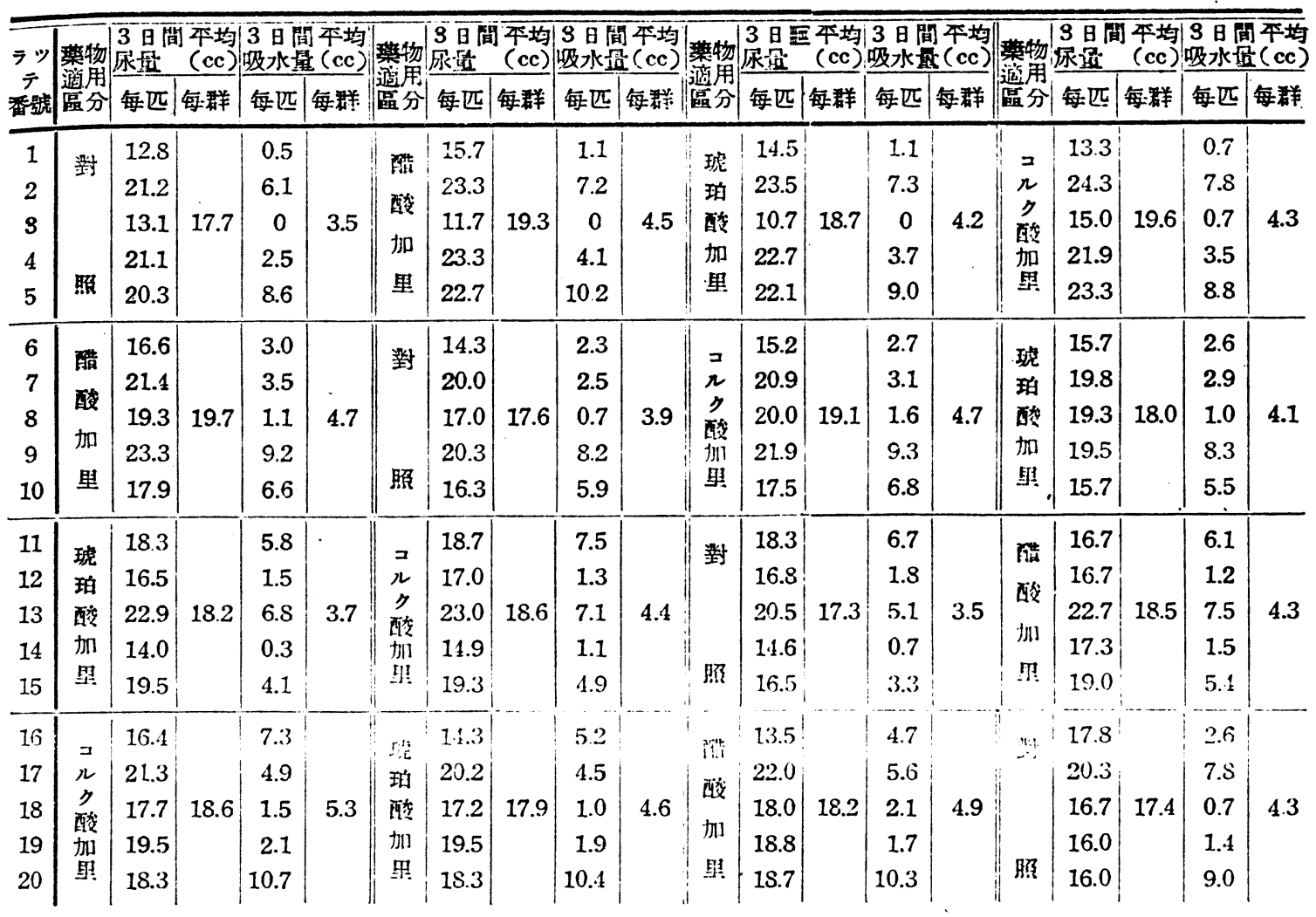

第19表 (1). 分散 分析表尿望.

\begin{tabular}{|c|c|c|c|c|c|c|c|}
\hline 要 & 因 & 楚 & 動 & 自由应 & 不偏分散 & $F_{0}$ & $\mathbf{F}$ \\
\hline 㿬 & 理 & \multicolumn{2}{|c|}{5.825} & 3 & 1.942 & 15.41 & $=9.78$ \\
\hline 誤 & 美 & \multicolumn{2}{|c|}{0.755} & 6 & 0.162 & & \\
\hline
\end{tabular}

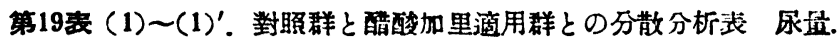

\begin{tabular}{|c|c|c|c|c|c|c|}
\hline 要 & 因 & 禁 县 & 自由度 & |不倨分散| & $F_{0}$ & $\mathbf{F}$ \\
\hline 對炤群と醋 & D間の虎理 & 4.06 & 1 & 4.06 & 32.22 & $>F_{\theta}^{1}(0.01)=13.74$ \\
\hline 䜒 & 差 。 & 0.755 & 6 & 0.162 & & \\
\hline
\end{tabular}

第19表 (1)〜(2)'. 對照群とコルク酸加里適用群との分散分析表 尿至.

\begin{tabular}{|c|c|c|c|c|c|c|}
\hline 要 & 因 & 動 & 自由度 & 不绳分散 & $F_{0}$ & $\mathbf{F}$ \\
\hline 䅉炤群とこル & 群との間の成理 & 4.35 & 1 & 4.35 & 34.52 & $F_{B}^{1}(0.01)=13.74$ \\
\hline 誝 & 差 & 0.755 & 6 & 0.162 & & \\
\hline
\end{tabular}




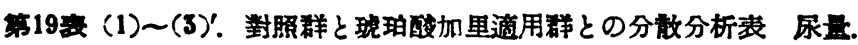

\begin{tabular}{|c|c|c|c|c|c|c|}
\hline 要 & 因 & 焚 助 & 自由度 & |不偏分散 & $F_{0}$ & $\mathrm{~F}$ \\
\hline \multicolumn{2}{|c|}{ 数昭群と琥珀酸加里投與群との間の虎理 } & 0.98 & 1 & 0.98 & \multirow{2}{*}{\multicolumn{2}{|c|}{$7.78>F_{8}^{1}(0.05)=5.99$}} \\
\hline 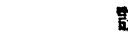 & 劷 & 0.755 & 6 & 0.162 & & \\
\hline
\end{tabular}

第19表 (2). 分散分析视吸水量

\begin{tabular}{|c|c|c|c|c|c|c|}
\hline 要 & 因 & 玟 & 自由度 & 不堀分散 & $F_{0}$ & $F$ \\
\hline t & 理 & 2.0119 & 3 & 0.6706 & 22.37 & )$=9.78$ \\
\hline 舀 & 盖 & 0.18 & 6 & 0.03 & & \\
\hline
\end{tabular}

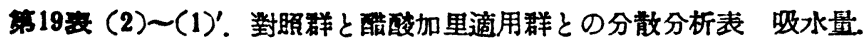

\begin{tabular}{|c|c|c|c|c|c|c|}
\hline 要 & 因 & 留 旌 & 自由度 & |不霍分散| & $F_{0}$ & F \\
\hline 對炤群と同 & D間の理 & 1.30 & 1 & 1.30 & 43.33 & $>F_{6}^{1}(0.01)=13.74$ \\
\hline 詇 & 差 & 0.18 & 6 & 0.03 & & - \\
\hline
\end{tabular}

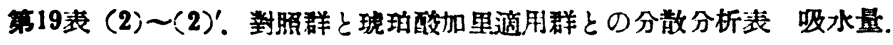

\begin{tabular}{|c|c|c|c|c|c|c|}
\hline 要 & 因 & 愁勤 & 自由度 & |不嚅分散 $\mid$ & $F_{0}$ & $\mathrm{~F}$ \\
\hline \multicolumn{2}{|c|}{ 對照群と琥珀酸加旦望與群との問の虎理 } & 0.245 & 1 & 0.245 & \multirow{2}{*}{\multicolumn{2}{|c|}{$8.17>\mathrm{F}_{6}^{1}(0.05)=5.99$}} \\
\hline 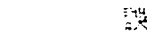 & 泚 & 0.18 & 6 & 0.03 & & \\
\hline
\end{tabular}

第19表 (2)〜(3)'. 䍈照群とコルク酸加里適用群との分散分析裴 吸水量.

\begin{tabular}{|c|c|c|c|c|c|c|}
\hline 要 & 因 & 禁 動 & 自由度 & |不倔分散| & $F_{0}$ & F \\
\hline 数炤群 $と コ n$ & の間の越理 & 1.33 & 1 & 1.33 & 44.33 & $>F_{\theta}^{1}(0.01)=13.74$ \\
\hline 䛊 & 宦 & 0.18 & 6 & 0.03 & & \\
\hline
\end{tabular}

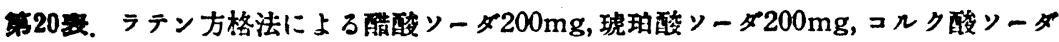
$250 \mathrm{mg} / \mathrm{kg}$ 經口投與による利尿及ご吸水寞验。

\begin{tabular}{|c|c|c|c|c|c|c|c|c|c|c|c|c|c|c|c|c|c|c|c|c|c|}
\hline \multirow{2}{*}{$\begin{array}{l}\% \\
\bar{\nabla} \\
\bar{F}\end{array}$} & \multicolumn{5}{|c|}{ 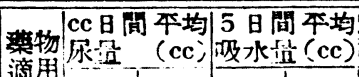 } & \multicolumn{5}{|c|}{ 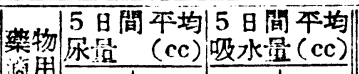 } & \multicolumn{6}{|c|}{ 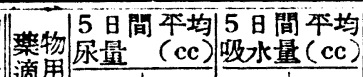 } & \multicolumn{5}{|c|}{ 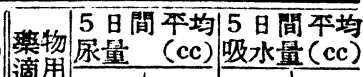 } \\
\hline & 蓲分 & 每匹匹 & 每群 & 每匹 & 每群 & 逼分 & 每匹 & 每群 & 每匹 & 每君 & $=$ & & 海匹 & 每群 & 每匹 & 每群 & 區分 & 每匹 & 每群 & 每匹 & 每群 \\
\hline 1 & $=$ & 16.5 & & 1.0 & & 4 & 13.3 & & 0.4 & & & & 15.5 & & 0.8 & & 碏 & 16.4 & & 1.4 & \\
\hline 2 & r & 19.5 & & 4.6 & & $\exists$ & 16.8 & & 3.6 & & & & 20.0 & & 3.7 & & 4 & 21.0 & & 5.7 & \\
\hline 8 & 酸 & 12.2 & 16.5 & 2.0 & 2.8 & & 11.1 & 13. & 1.8 & 2. & ? & & 12.0 & 16.7 & 1.8 & 2.7 & $y$ & 12.5 & 17.7 & 2.4 & 3.4 \\
\hline 4 & iे & 15.6 & & 3.2 & & & 11.8 & & 2.6 & & & & 16.5 & & 3.4 & & 1 & 18.6 & & 3.9 & \\
\hline 5 & $\not x$ & 18.6 & & 3.4 & & 照 & 16.0 & & 2.6 & & & & 19.4 & & 3.8 & & 8 & 20.0 & & 3.6 & \\
\hline 6 & & 2.5 & & 1.2 & & 醇 & 8.9 & & 0.2 & & $=$ & & 14.0 & & 2.6 & & 淛 & 11.4 & & 0.4 & \\
\hline 7 & 珽 & 15.8 & & 2.1 & & & 15.4 & & 1.8 & & & & 18.2 & & 2.6 & & & 16.9 & & 2.6 & \\
\hline 8 & 酸 & 42.4 & 14.2 & 1.6 & 1.6 & 醇 & 12.4 & 12 & 0.8 & 1. & ? & & 15.2 & 16.5 & 1.2 & 2.3 & & 15.7 & 15.6 & 2.0 & 2.0 \\
\hline 9 & $i$ & 14.6 & & 1.8 & & 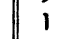 & 14.8 & & 1.5 & & & & 21.9 & & 3.4 & & & 20.5 & & 3.5 & \\
\hline 10 & $\not x$ & 15.5 & & 1.4 & & & 9.6 & & 1.7 & & 3 & & 13.1 & & 1.8 & & 赆 & 13.3 & & 15 & \\
\hline
\end{tabular}




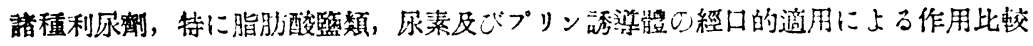

\begin{tabular}{|c|c|c|c|c|c|c|c|c|c|c|c|c|c|c|c|c|c|c|c|c|}
\hline $\begin{array}{l}11 \\
12 \\
13 \\
14 \\
15\end{array}$ & $\begin{array}{l}\text { 醌 } \\
\text { 酸 } \\
\text { y } \\
1 \\
\text { ダ }\end{array}$ & $\begin{array}{l}15.2 \\
13.4 \\
20.5 \\
13.4 \\
15.4\end{array}$ & 15.6 & $\begin{array}{l}2.4 \\
2.2 \\
7.2 \\
2.2 \\
3.4\end{array}$ & 3.5 & $\begin{array}{l}\text { 琥 } \\
\text { 珀 } \\
\text { 酸 } \\
\text { y } \\
1 \\
\text { ダ }\end{array}$ & $\begin{array}{l}14.6 \\
12.6 \\
17.3 \\
13.1 \\
12.5\end{array}$ & 14.0 & $\begin{array}{l}2.0 \\
2.0 \\
6.2 \\
1.9 \\
1.8\end{array}$ & 2.8 & 照 & $\begin{array}{l}17.0 \\
16.3 \\
18.8 \\
13.8 \\
15.7\end{array}$ & 16.3 & $\begin{array}{l}3.0 \\
2.3 \\
5.4 \\
2.2 \\
2.5\end{array}$ & 3.1 & $\begin{array}{c}a \\
n \\
ク \\
\text { 酸 } \\
y \\
1 \\
\not\end{array}$ & \begin{tabular}{|}
17.5 \\
18.3 \\
20.7 \\
16.6 \\
16.9
\end{tabular} & 18.0 & $\begin{array}{l}4.0 \\
3.5 \\
7.6 \\
3.7 \\
4.1\end{array}$ & 4.6 \\
\hline $\begin{array}{l}16 \\
17 \\
18 \\
19 \\
20\end{array}$ & 對 & $\begin{array}{l}17.8 \\
16.2 \\
10.8 \\
14.6 \\
13.1\end{array}$ & 14.5 & $\begin{array}{l}5.2 \\
3.7 \\
0.2 \\
1.4 \\
1.4\end{array}$ & 2.4 & $\begin{array}{c}z \\
\mu \\
y \\
y \\
\text { 酸 } \\
y \\
1 \\
\text { \& }\end{array}$ & $\begin{array}{r}16.1 \\
19.1 \\
9.8 \\
15.2 \\
12.1\end{array}$ & 14.5 & $\begin{array}{l}3.2 \\
6.1 \\
0.2 \\
2.3 \\
0.8\end{array}$ & 2.5 & 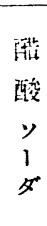 & $\begin{array}{r}19.8 \\
19.4 \\
13.8 \\
19.2 \\
8.4\end{array}$ & 16.1 & $\begin{array}{l}5.5 \\
5.0 \\
0.5 \\
2.6 \\
0.8\end{array}$ & 2.9 & $\begin{array}{l}\text { 琥 } \\
\text { 玷 } \\
\text { 酸 } \\
y \\
1 \\
\text { ダ }\end{array}$ & $\begin{array}{r}18.6 \\
29.0 \\
12.7 \\
18.4 \\
9.2\end{array}$ & 15.8 & $\begin{array}{l}5.6 \\
6.2 \\
0.4 \\
2.1 \\
0.1\end{array}$ & 3.0 \\
\hline
\end{tabular}

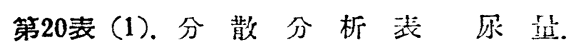

\begin{tabular}{|c|c|c|c|c|c|c|c|}
\hline 要 & 因 & 鶖 & 動 & 自由度 & 不湼分敬 & $F_{0}$ & F \\
\hline 處 & 理 & & & 3 & 1.445 & 11.29 & $=9.78$ \\
\hline 諤 & 差 & & & 6 & 0.128 & & \\
\hline
\end{tabular}

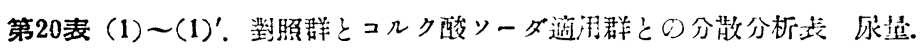

\begin{tabular}{|c|c|c|c|c|c|}
\hline 要 & 因 & 愁 動 & 自由正不谁分政 & $\mathrm{F}_{0}$ & $\mathrm{~F}$ \\
\hline 招群とコルク & w成儿减理 & 3.51 & 3.51 & 27.11 & $\forall F_{b}^{1}(0.01)=13.7 t$ \\
\hline 秱 & & 0.77 & 0.129 & & \\
\hline
\end{tabular}

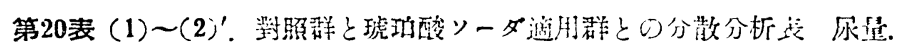

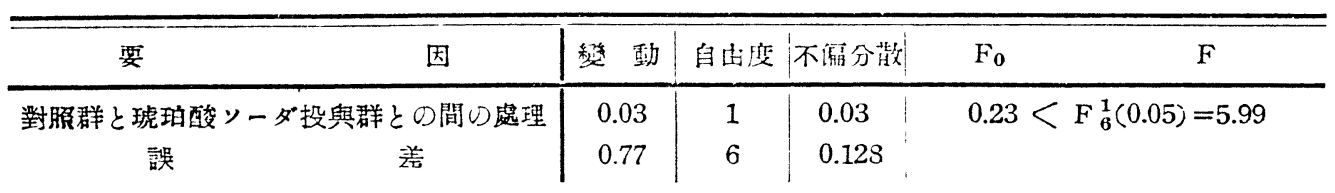

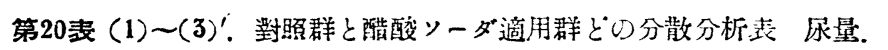

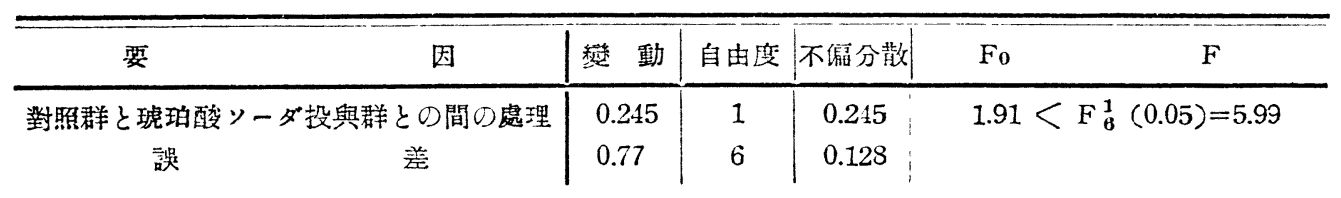

第20表 (2). 分散 分析表 吸水量.

\begin{tabular}{|c|c|c|c|c|c|c|c|}
\hline 要 & 因 & 敕 & 動 & 自由度 & 不㴜分散 & $F_{0}$ & $\mathrm{~F}$ \\
\hline 處 & 理 & \multicolumn{2}{|c|}{0.9225} & 3 & 0.3075 & $\cdot 7.85$ & $=4.76$ \\
\hline 誤 & 差 & \multicolumn{2}{|c|}{0.2325} & 6 & 0.03875 & & \\
\hline
\end{tabular}

第20表 $(2) \sim(1)^{\prime}$. 對昭群とコルク酸ソーダ適用群との間の分散分析表 吸水量.

\begin{tabular}{|c|c|c|c|c|c|c|}
\hline 要 & 因 & 禁 動 & 自由度 & 不偏分散 & $F_{0}$ & $\mathrm{~F}$ \\
\hline 對炤群とコルク & の間心處理 & 0.78 & 1 & 0.78 & \multirow{2}{*}{\multicolumn{2}{|c|}{$20.12 \cdots>F_{6}^{1}(0.01)=13.74$}} \\
\hline 。譟 & 美 & 0.2325 & 6 & 0.03875 & & \\
\hline
\end{tabular}


第20表 (2)〜(2)'. 對照群と酛酸ソーダ適用群との分散分析㝨 吸水量.

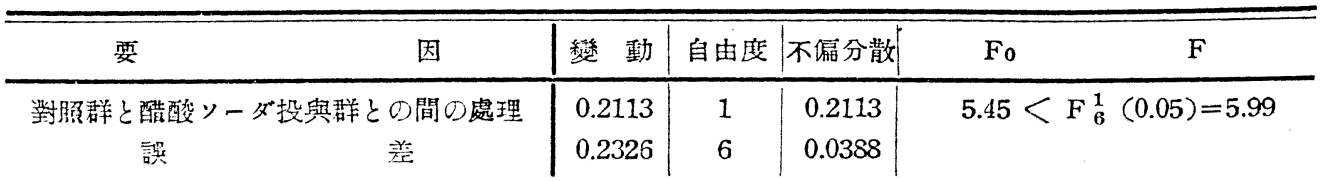

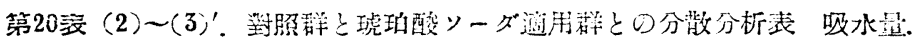

\begin{tabular}{|c|c|c|c|c|c|c|}
\hline 要 & 因 & 梖綡 動 & 自由政 & 不倔分散 & $F_{0}$ & $F$ \\
\hline 對炤群と琥珀 & との間の處理 & 0.02 & 1 & 0.02 & $0.5 \cdots$ & $05)=5.93$ \\
\hline 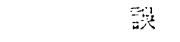 & 禁 & 0.2325 & 6 & 0.0389 & & \\
\hline
\end{tabular}

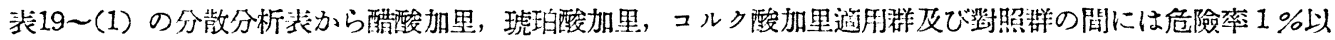

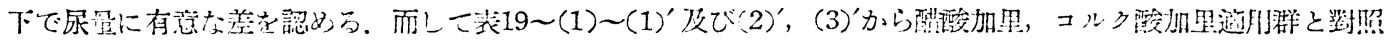

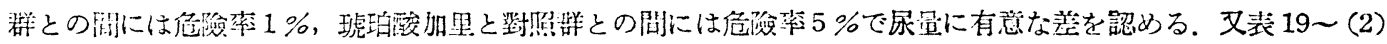

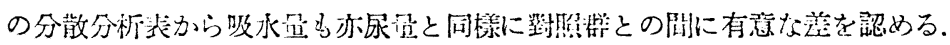

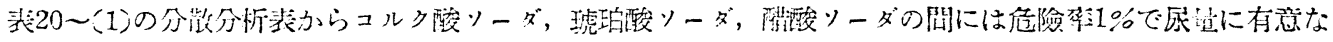

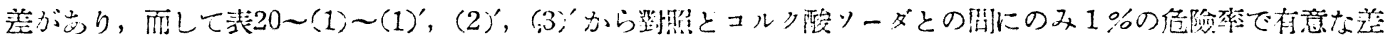

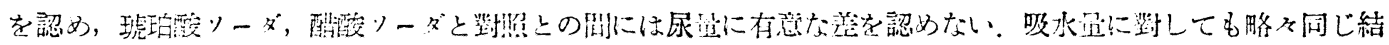

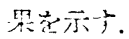

第 2 項 キサンテン誘蓄䄈とコルク酸加里の利尿作用比較.

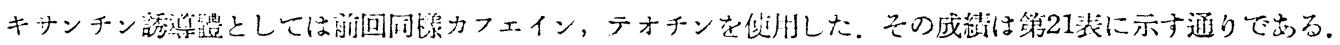

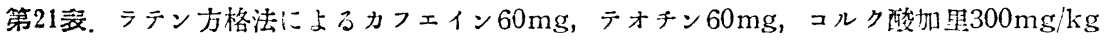

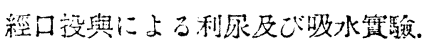

\begin{tabular}{|c|c|c|c|c|c|c|c|c|c|c|c|c|c|c|c|c|c|c|c|c|}
\hline \multirow{2}{*}{\begin{tabular}{c|} 
ラッ \\
テ \\
番號
\end{tabular}} & \multirow{2}{*}{\multicolumn{3}{|c|}{ 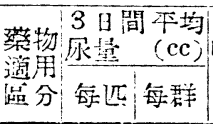 }} & \multicolumn{2}{|c|}{$\begin{array}{l}3 \text { 日間平均 } \\
\text { 吸水量 (cc) }\end{array}$} & \multirow{2}{*}{$\begin{array}{l}\text { 適物 } \\
\text { 透分 } \\
\end{array}$} & \multicolumn{2}{|c|}{$\begin{array}{l}3 \text { 日間平均 } \\
\text { 厡音 (cc) }\end{array}$} & \multicolumn{2}{|c|}{$\begin{array}{l}3 \text { 日間平均 } \\
\text { 吸水量 (cc) }\end{array}$} & \multirow{2}{*}{$\begin{array}{l}\text { 菜物 } \\
\text { 適书 } \\
\text { 嵒分 }\end{array}$} & \multicolumn{4}{|c|}{ 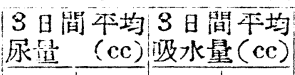 } & \multirow{2}{*}{ 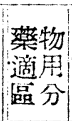 } & \multicolumn{4}{|c|}{$\begin{array}{l}3 \text { 日間 平均 } 3 \text { 日間本均 } \\
\text { 家点 (c) 吸水量 (cc) }\end{array}$} \\
\hline & & & & 每近 & 每群 & & 每匹 & 每群 & 每匹 & 每群 & & 每匹 & 每群 & 每匹 & 每群 & & 每匹 & 每群 & 每匹 & 每群 \\
\hline $\begin{array}{l}\text { I } \\
2 \\
3 \\
4 \\
5\end{array}$ & $\begin{array}{l}7 \\
7 \\
x \\
1 \\
2\end{array}$ & \begin{tabular}{r|}
15.4 \\
19.1 \\
7.4 \\
19.7 \\
15.0
\end{tabular} & 15.3 & $\begin{array}{l}1.7 \\
4.0 \\
0.7 \\
8.0 \\
2.3\end{array}$ & 3.3 & $\begin{array}{c}コ \\
\text { ル } \\
ク \\
\text { 酸 } \\
\text { 加 } \\
\text { 里 }\end{array}$ & $\begin{array}{r}14.5 \\
20.9 \\
7.3 \\
21.9 \\
14.9\end{array}$ & 15.9 & $\begin{array}{l}1.0 \\
7.0 \\
0.7 \\
9.3 \\
1.7\end{array}$ & 3.9 & 数 & $\begin{array}{r}13.3 \\
18.7 \\
8.2 \\
18.3 \\
12.1\end{array}$ & 14.1 & $\begin{array}{l}0.3 \\
3.7 \\
1.3 \\
6.7 \\
1.0\end{array}$ & 2.6 & $\begin{array}{l}\text { テ } \\
\text { オ } \\
\text { チ } \\
\text { ン }\end{array}$ & $\mid \begin{array}{r}15.1 \\
19.5 \\
7.3 \\
20.0 \\
14.3\end{array}$ & 15.2 & $\begin{array}{c}2.3 \\
4.7 \\
0 \\
8.8 \\
1.3\end{array}$ & 3.4 \\
\hline $\begin{array}{c}6 \\
7 \\
8 \\
9 \\
10\end{array}$ & $\begin{array}{l}\text { テ } \\
\text { オ } \\
\text { チ } \\
\text { ン }\end{array}$ & $\begin{array}{r}9.0 \\
13.0 \\
16.5 \\
16.7 \\
12.1\end{array}$ & 13.5 & $\begin{array}{l}0.3 \\
1.7 \\
3.0 \\
2.0 \\
0.7\end{array}$ & 1.5 & $\begin{array}{l}\text { J } \\
7 \\
x \\
1 \\
y\end{array}$ & $\begin{array}{l}10.5 \\
14.5 \\
14.5 \\
16.6 \\
11.8\end{array}$ & 13.6 & $\begin{array}{l}0.7 \\
1.7 \\
1.7 \\
2.3 \\
0.3\end{array}$ & 1.3 & $\begin{array}{c}コ \\
u \\
\eta \\
\text { 酸 } \\
\text { 加 } \\
\text { 里 }\end{array}$ & $\begin{array}{l}11.6 \\
13.1 \\
17.1 \\
18.3 \\
14.4\end{array}$ & 14.9 & $\begin{array}{l}1.7 \\
2.0 \\
4.0 \\
4.0 \\
1.7\end{array}$ & 2.7 & 涅 & \begin{tabular}{l|}
12.3 \\
13.9 \\
14.5 \\
17.2 \\
13.2
\end{tabular} & 14.2 & $\begin{array}{l}2.0 \\
3.0 \\
1.0 \\
2.7 \\
1.7\end{array}$ & 2.1 \\
\hline $\begin{array}{l}11 \\
12 \\
13 \\
14 \\
15\end{array}$ & 對 & $\begin{array}{r}13.9 \\
17.7 \\
18.9 \\
6.0 \\
18.0\end{array}$ & 14.4 & $\begin{array}{c}2.0 \\
4.3 \\
5.3 \\
0 \\
8.0\end{array}$ & 3.9 & ע & $\begin{array}{r}15.6 \\
17.1 \\
19.0 \\
6.9 \\
19.3\end{array}$ & 15.6 & $\begin{array}{l}1.0 \\
2.7 \\
4.7 \\
0.3 \\
7.3\end{array}$ & 3,2 & $\begin{array}{l}\text { カ } \\
7 \\
x \\
1 \\
y\end{array}$ & \begin{tabular}{|r}
13.8 \\
16.6 \\
18.2 \\
5.4 \\
20.1
\end{tabular} & 14.8 & $\begin{array}{c}1.0 \\
2.7 \\
4.0 \\
0 \\
9.7\end{array}$ & 3.4 & $\begin{array}{l}z \\
ル \\
ク \\
\text { 酸 } \\
\text { 加 } \\
\text { 里 }\end{array}$ & $\begin{array}{r}.15 .3 \\
18.6 \\
19.5 \\
7.8 \\
21.3\end{array}$ & 16.5 & $\begin{array}{l}1.7 \\
3.3 \\
5.7 \\
0.3 \\
9.7\end{array}$ & 4.1 \\
\hline
\end{tabular}




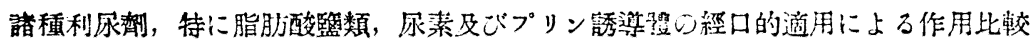

\begin{tabular}{|c|c|c|c|c|c|c|c|c|c|c|c|c|c|c|c|c|c|c|c|c|}
\hline 16 & ב & 7.7 & & 0 & & 轱 & 8.1 & & 0 & & $\bar{\tau}$ & 10.3 & & 1.0 & & & 10.5 & & 1.0 & \\
\hline 17 & $n$ & 21.1 & . & 9.3 & & & 186 & & 6.3 & & 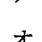 & 20.2 & & 8.3 & & カ & 21.1 & & 8.7 & \\
\hline 18 & 酸 & 17.9 & 16.2 & 4.7 & 4.8 & & 16.7 & 14.8 & 4.0 & 3.1 & & 16.5 & 16.1 & 3.3 & 4.4 & I & 16.7 & 15.9 & 3.7 & 4.3 \\
\hline 19 & 加 & 19.6 & & 6.3 & & & 17.9 & & 3.7 & & チ & 19.2 & & 6.3 & & $\begin{array}{l}1 \\
y\end{array}$ & 18.9 & & 6.2 & \\
\hline 20 & 里 & 14.8 & & 3.7 & & 腹 & 12.9 & & 1.3 & & ン & 14.5 & & 3.0 & & & 12.7 & & 2.0 & \\
\hline
\end{tabular}

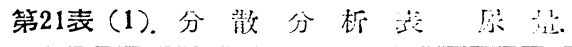

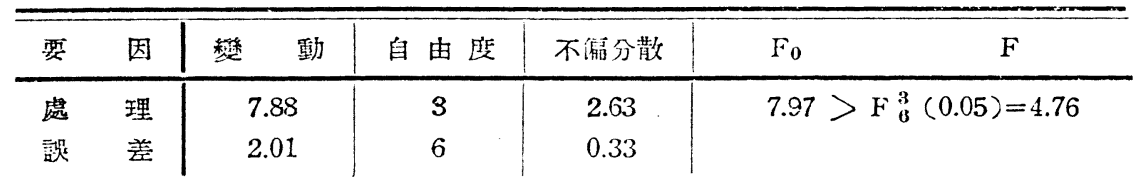

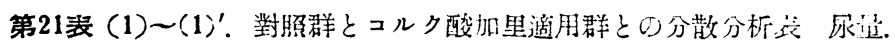

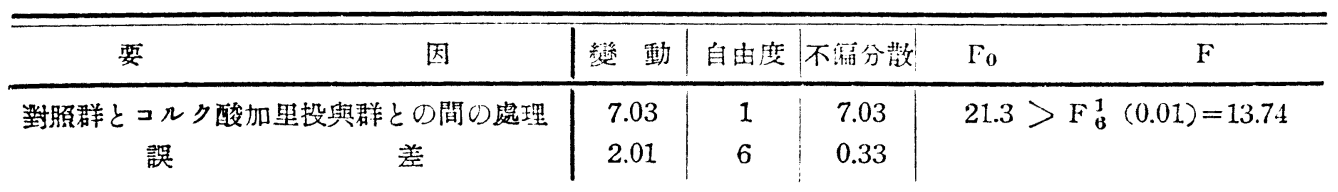

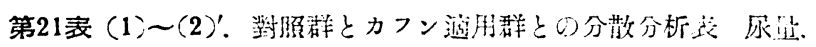

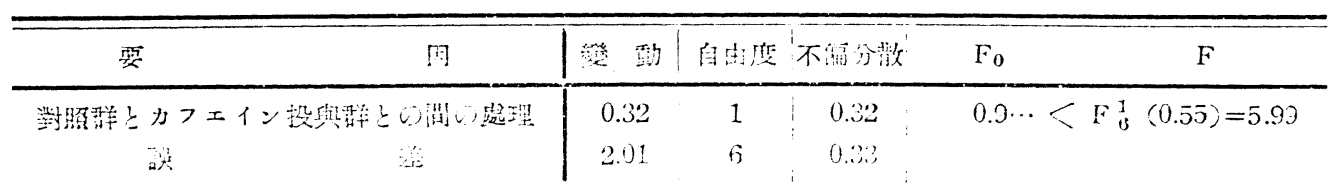

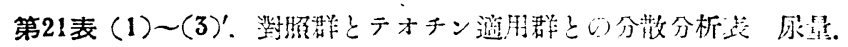

\begin{tabular}{|c|c|c|c|c|c|c|}
\hline 要 & 因 & 赫 動 & 兒证提 & 不黇分散 & $F_{0}$ & $\mathrm{~F}$ \\
\hline \multicolumn{2}{|c|}{ 對照群とテォチン投與群との間の處理 } & 0.72 & 1 & 0.72 & \multirow{2}{*}{\multicolumn{2}{|c|}{$2.1 \cdots>F_{8}^{1}(0.05)=5.99$}} \\
\hline 誤 & 差 & 2.01 & 6 & 0.33 & & \\
\hline
\end{tabular}

第21表 (2). 分散 分析站吸水量.

\begin{tabular}{|c|c|c|c|c|c|c|}
\hline 要 & 因 & 變 動 & 自由度 & 不濡分散 & $\mathrm{F}_{0}$ & F \\
\hline 處 & 理 & 6.55 & 3 & 2.183 & 6.27 & $>F_{6}^{3}(0.05)=4.76$ \\
\hline 詥 & 差 & 2.09 & 6 & 0.348 & & \\
\hline
\end{tabular}

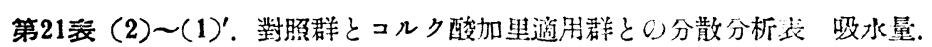

\begin{tabular}{|c|c|c|c|c|c|c|}
\hline 要 & 因 & 紜娄 動 & 自由度 & 不嚅分散 & $\mathrm{F}_{0}$ & $\mathrm{~F}$ \\
\hline 對照群とカ & の間の處理 & 6.480 & 1 & 6.480 & 18.62 & $>F_{6}^{1}(0.01)=13.74$ \\
\hline 誤 & 差 & 2.09 & 6 & 0.348 & & \\
\hline
\end{tabular}

第21表 (2)〜(2;'. 對照群とカフェイン邀用群との分散分析表 吸水量.

\begin{tabular}{|c|c|c|c|c|c|c|}
\hline 要 & 因 & 綮 動 & 自由度 & |不鼬分散 & $F_{0}$ & $F$ \\
\hline \multicolumn{2}{|c|}{ 對照群とカフェイン投與群との間の處理 } & 1.125 & 1 & 1.125 & \multirow{2}{*}{\multicolumn{2}{|c|}{$3.2 \cdots<F_{B}^{1}\left(0.0 \mathcal{G}^{\circ}\right)=5.99$}} \\
\hline 哭 & 差 & 2.09 & 6 & 0.348 & & \\
\hline
\end{tabular}




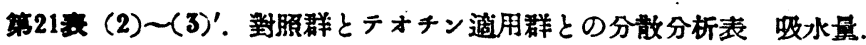

\begin{tabular}{|c|c|c|c|c|c|c|}
\hline 要 & 因 & 焚 动 & 自由度 & |不儒分散 $\mid$ & $F_{0}$ & $\mathrm{~F}$ \\
\hline 對炤群とテ & D間の虎理 & 1.23 & 1 & 1.28 & 3.6 & (5) $=5.99$ \\
\hline 歌 & 差 & 2.09 & 6 & 0348 & & \\
\hline
\end{tabular}

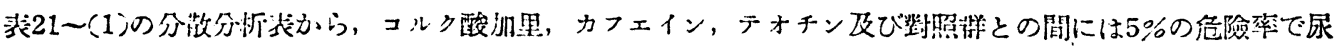

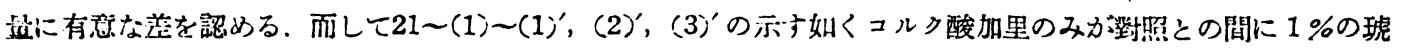

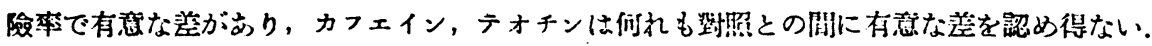

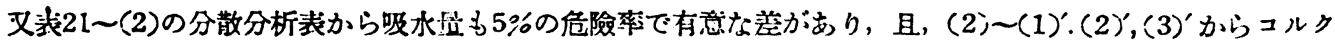

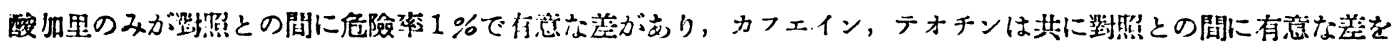
鲶められない。

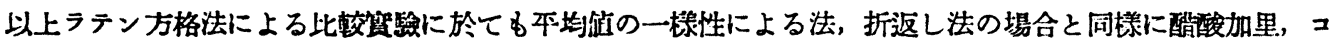

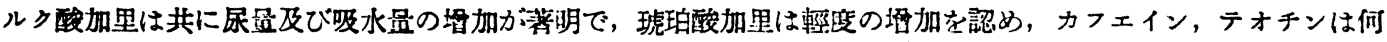

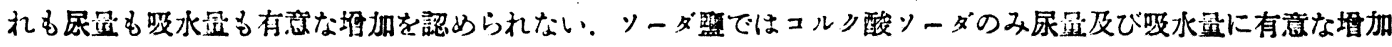
を登明し，酷酸，琥珀酸つッータ盟には有意な㙁加を認められない。

\section{第IV古 總括竝に考察}

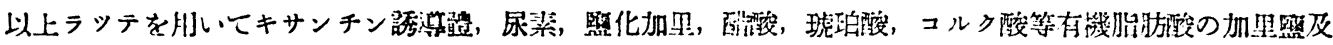

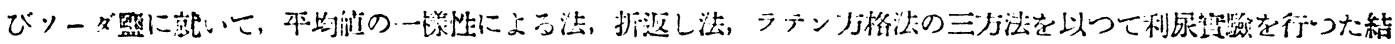

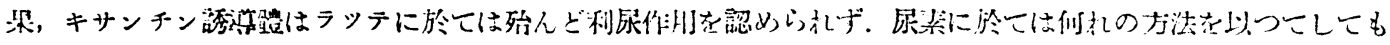

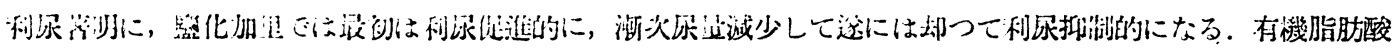

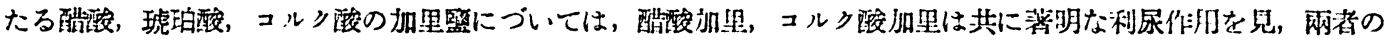

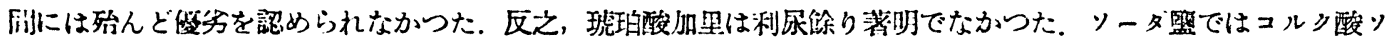

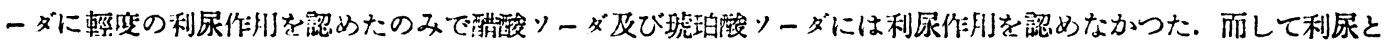

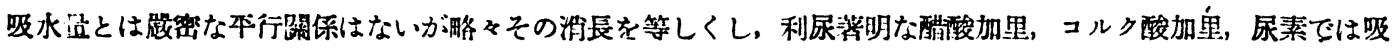

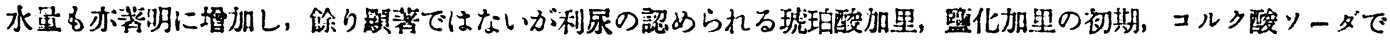

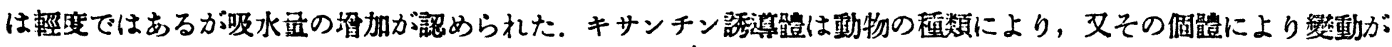
著しく，鬼及び人に於て影著に大に於ては不定で，猫に於ては利尿を見ないと云われているが，ラッテについて

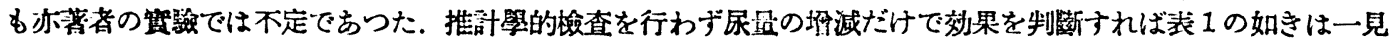

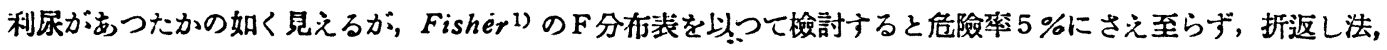

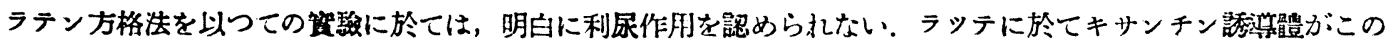

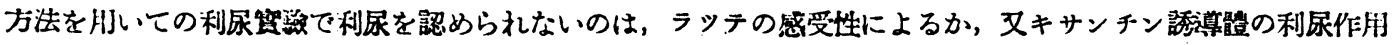
は短かくそのため一日の尿语としては埇堿が著明でないのか，或は他の原因によるのか，これは尿素の都明な利

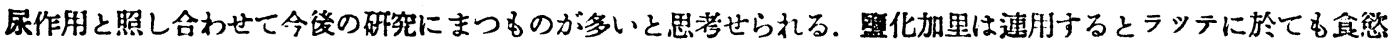

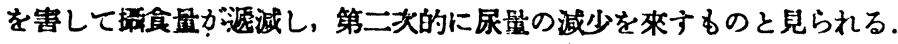

有機脂肪酸焉類の利尿作用は上述のるのに比すると極めて梅雜で，その體內分解過程が漸头解明せられては

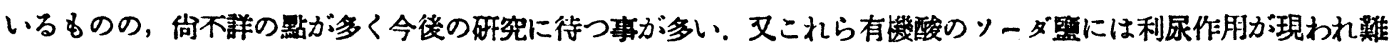
いがュルク酸ソータ゚のみ輕度の利尿を見得たことは注目すべき點と思う。

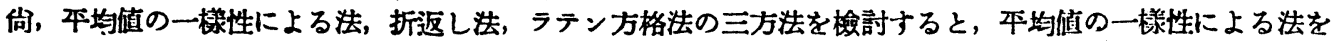

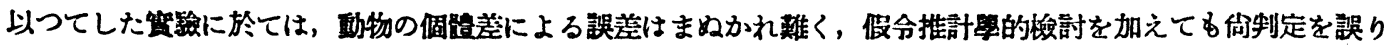

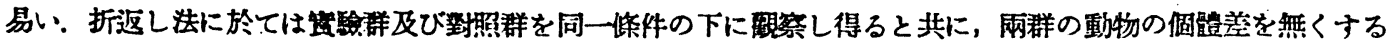

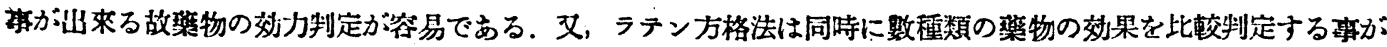

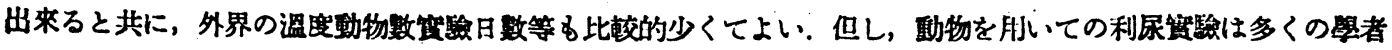


の指商した如く極わて變動し易いものでむるから，出來る限り誤前の少い折汳し法又はラテン方格法を以つて行

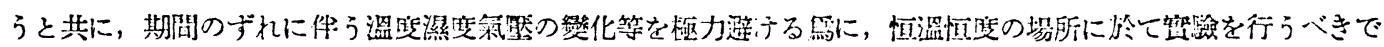

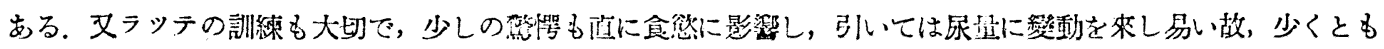
6 カ月位手許に於て充分に馴らしたものを纬いるねばならない。

\section{第V草 結 論}

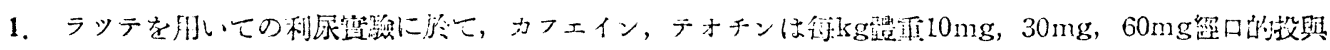

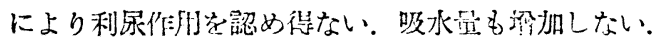

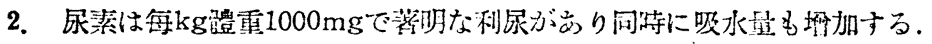

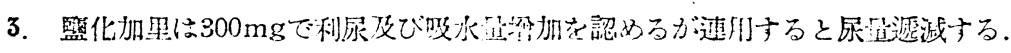

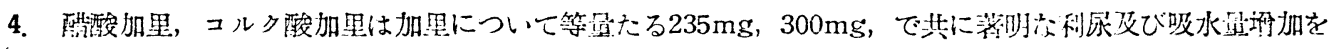

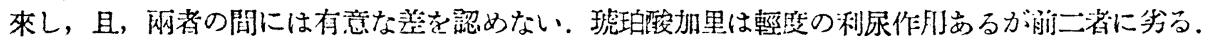

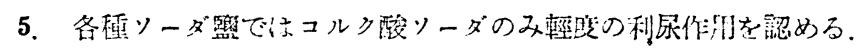

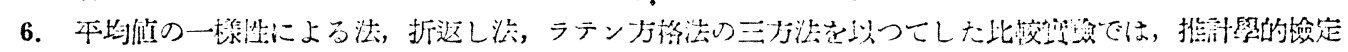
を加えると略々同一の結果を得た。

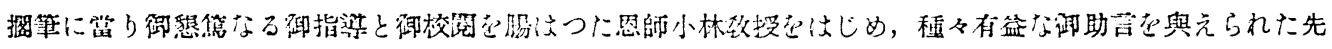

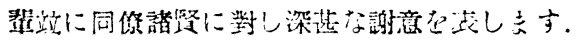

交献

1) Fisher, R. A.: Staiistical Methods for Research Workers, Oliver and Boys, London (1936).

2) Donaldson: The Rat, Wister Inst. 2nd. Ed. (1921).

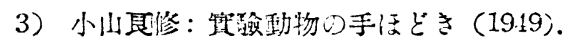

4) Spiro: Arch. exper. Path. u. Pharmakol., 41, 1.48 (1898).

5) Adorph: Am. J. Physiol. 63, 432 (1923).

6) Thompson, WH.: J. Physiol. 25, 487 (1899-1900).

7) Sollman: Am. J. Physiol. 9, 425 (1903): Arch. exper. Path. u. Pharmakol. 46, 1 (1901).

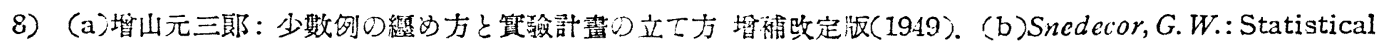
Methods (1946).

9）（a）田村, 渡遥，夏，小烃源，木原：Proc. Imp. Acad. 2, 434 (1923)。（b) 木原玉汝：同誌，4，418 (1928). (c) 古川利雍: 東京醫學會雜誌, 42, 1072 (1928). (d) 仁科敏郎: Proc. Imp. Acad. 2, 442

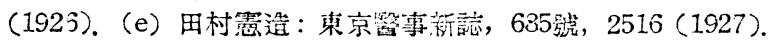

10) Cushny: The secretion of the Urine, London 127 (1927).

11) Tamura et al.: Proc. Imp. Acad. 2, 7, (1926).

12) Roy: Cambridge Philos. Soc. 4, 110 (1881).

13) Gottlieb u. Magnus: Arch, exper. Path. u. Pharmakol., 45, 223 (1901).

14) Schwarz: 同誌, 53, 49 (1905).

15) Cushny and Lambie: J. Physiol. 155, 270 (1921).

16) Cavazzini u. Rebustells: Arch. perle Scienze Med, (1891).

17) Munk u. Senator: Virchow's Arch. (1888).

18) Gremels, H.: Arch. exper. Path. u. Pharmakol. 190, 207 (1938).

19) Ellinger: Klin. Wschr. 1922, 249.

20）夏禹鼎：東京醫會誌，42, 1305 (1928).

21). Bock: Arch. exper. Path. u. Pharmakol. 57, 177 (1907) 及び 53, 227 (1908). 
22) Miller: J. biol. Chem. 55, 45 (1925).

23) Limbeck: Arch. exper. Path. u. Plarmakol. 25, 69 (1889).

24) Hofmeister: 同誌, 25, 1 (1889).

25) Magnus. 同誌, 42, 250 (1889).

26) Myss : Deutch. Arch. Klin. Med. 111, 93 (1913).

27) Blum: Compt. rend. Soc. biol. (1921).

28) Zander: Ztschr. exper. Path. u. Therap (1913).

29) Physiol. Reviews: 29, 127 (1949).

30) Bunge, G.: Ztschr. Biol. 9, 104 (1973).

31) Gerarde, P. J.: Doctral sur sciences, paris (1912).

32) Meyer, L. F. u. Cohn, S.: Ztschr. Kinderheilk. 2, 360 (1911).

33) Blum, L. Aubel, E. et Hausknecht, R.: Compt. rend. Soc. bioi. 84, 360 (1921).

34) Bloch, E.: Ztschr. Klin. Med. 106 (1907).

35) Baer, J. and Blum, L.: Beitr. Chem. Physiol. u. Pathol. 10, 80 (1907); 11, 101 (1908).

36) Rose, W. C. et al.: J. Pharmacol. \& Exper. Therap. 24, 123 及び 147 (1925); 25, 59 (1925).

37) Harching, V.J. et al.: 同誌 36,525 (1926).

38）小林芳人: 日樂物誌, 31, 44 (1941).

39）小林苊人及び大橋茂：日禁理誌，44，第20回日本薬理學會記事 $3 \S(1948)$.

40) 椎名俊夫：日冧理誌， 47,56 (1951).

41) 清川謹三：同誌, 47, 32 (1951).

42) Baer. B. D.: J. Pharmacol. \& Exper. Therap. 88, 366 (1946). 
from $90 \%$ of C. H. C. R. contained. Oral toxicity tomice, local irritant action (examined on conjunctiva of rabbits, human tongues and gastric mucosa of dogs and also clinical side effects of these mixtures of most efficatious ratios did not significantly differ from those of C.H.C.R., the fact revealing no potentiation in such aspects. These mixtures proved, to be superior in anthelmintic efficacy and less toxic and less irritant than hexylresorcinol. Some physical changes such as a fall of melting point and a lowering of interfacial tension of solution are supposed to be important factors in the imechanism of anthelmintic potentiation of these mixtures.

\section{Author}

17. KımızukA, Michio. Department of Pharmacology, Faculty of Medicine, University of Tokyo, Tokyo $A$ comparison of the dizretic action of xanthines, urea, and salts organic acids by oral administration (pp. 185-208) Tables 21

Experiments were performed under the normal physiological conditions on a caged rat with free access to water. The diuretic action and the amount of water drunk were compared at regular. intervals after the oral administration of diuretics of various kinds, such as coffein, theocin, urea, potassium chloride, potassium and sodium salts of acetic, succinic and suberic acid. All the experiments were planned statistically and carried out with the method of uniformity test, and $_{\text {i }}$ of cross test as, well as with Latin: square method. First, in the method of uniformity test, $10 \mathrm{mg}, 30 \mathrm{mg}$ and 60. $\mathrm{mg}$. of caffein and theocin were respectively administered per $\mathrm{kg}$ body. weight, but neither diuretic action nor an increase in the amount of water drunk were recognized. Then, 1,000 $\mathrm{mg}$ of urea and $300 \mathrm{mg}$ per $\mathrm{kg}$ of potassium chloride were administered. In the case of urea, a remarkable diuretic effect and an increase in the amount of water drunk were recognized. In the case of potassium chloride, temporary diuretic effect was found immediately after its administration and then, the amount of urine gradual. 1y decreased and in 5 or 6 days became smaller than before the administration. In the case where $23.5 \mathrm{mg}$ of potassium acetate, $23 \mathrm{mg}$ of potassium succinate and $30 \mathrm{mg}$ of potassium suberate kneaded with a constant amount of wheat flour respectively (each dose is equimolar to the other) were administered, neither diuretic effect nor increase in amount of water drunk was observed, whereas with doses ten times as much as the doses of these compounds respectively, all caused distinct diuretic and increase in the amount of water drunk, although the effect of potassium succinate is less remarkable than those of the other two. Next, the experiments were made by the method of cross test. In this case, too, almost the same distinct diuretic effect and increase in the am ount of water were observed, by using potassium acetate and potassium usberate. Furthermore, the results obtained by the Latir-square method with those compounds were the same as those of the above-mentioned two methods. When experiments were carried. out in the same manner as before with their sodium salts instead of potassium salts, suberate showed a slight diuretic effect, while no diuretic action was recognized in the cases of both acetate and succinate.

Author

18. Murano, Tadashi. Department of Pharmacology, Osaka City Medical. School, Osaka Further stu- 